\title{
Pathogenesis and Diseases of the Central Nervous System Caused by Murine Coronaviruses
}

\author{
Samuel Dales and Robert Anderson
}

\section{INTRODUCTION}

This chapter is an account of studies of central nervous system (CNS) diseases connected with neurotropic variants of MCV such as J. Howard Muller Virus (JHM) and A59 and deals with animal models that may have relevance to an understanding of human diseases of putative viral etiology such as multiple sclerosis (MS). From the time of (JHMV) isolation from paralyzed mice by Cheever et al. (1949) and Bailey et al. (1949), this agent and related strains have provided copious data about encephalitic and demyelinating diseases in rodents. To date, however, any possible connection between murine coronavirus $(\mathrm{MCV})$ and $\mathrm{MS}$ is tenuous. The reported isolation of coronavirus (CV) particles from MS patients' brain (Burks et al., 1980) or electron microscopic visualization of CV-like particles in brain tissue of one MS patient (Tanaka et al., 1976), require confirmation. An older report of JHMV-induced panencephalitis in monkeys (Kersting and Pette, 1956), however, has been confirmed by Murray et al. (1992a) in their description of demyelinative disease in several monkey

SAMUEL DALES - Cytobiology Group, Department of Microbiology and Immunology, The University of Western Ontario, London, Ontario, N6A 5Cl Canada. ROBERT ANDERSON • Department of Microbiology and Immunology, Dalhousie University, Halifax, Nova Scotia, B3H 4H7 Canada.

The Coronaviridae, edited by Stuart G. Siddell, Plenum Press, New York, 1995. 
species. This finding, coupled with the identification of viral RNA and protein within demyelinative plaques in human brain tissue from MS patients (Murray et al., 1992b; Stewart et al., 1992), are highly provocative data concerning an involvement of $\mathrm{CV}$ in the etiology of MS. However, a cautious evaluation of these results may be in order, in view of the recent demonstration of genomic and antigenic relatedness between the $\mathrm{N}$ protein of JHMV and the microtubuleassociated protein tau (Pasick et al., 1994).

The disease process associated with CV infection is highly variable, both in animals and at the cellular level, depending on the virus, cell types, and host species. In view of the voluminous literature on the subject, this relatively brief review is concerned primarily with disease processes in rodents infected by murine CVs and emphasizes infections of neural cells and pathogenesis in the CNS.

\section{VIRUS-CELL INTERACTIONS RELATED TO PATHOGENESIS AND DISEASE}

To comprehend the overall disease process elicited by neurotropic MCV, one should consider three major parameters. First, it is necessary to consider the complex organization of CNS tissue, involving a variety of cell types and lineages, that provides a great diversity of cell-cell interactions. Second, one must consider the highly error-prone synthesis of $\mathrm{CV}$ genomes that can undergo a high frequency of recombination, generating rapidly evolving mutants or variants (Lee et al., 1991; Lai, 1990). Such variants manifest altered tropism and virulence, as detailed in Section IV. Third, one must keep in mind the effects of host immunity evoked by CV infections. These responses, primarily of the cellular type, but also to some extent humoral, can modulate pathogenesis and disease, as described in Section III.

\section{A. Correlations between Infections in Vivo and with Explanted Neurons and Glia}

Infections of different tissues and organs in vivo develop according to the MCV type and the route of inoculation employed. The natural means for initiating infection is through intranasal (IN) instillation of virus, but introduction through intraperitoneal (IP) and intracranial (IC) injections is also commonly employed. Neonates and juveniles usually succumb more rapidly than adults, developing fulminant infections manifested by widespread destruction of tissues. In the CNS an early onset acute encephalitis develops.

In adult mice, responses are variable depending on the MCV type and the genetic constitution of the host, as discussed in more detail in Section IV. When adult mice are challenged intranasally with the highly virulent murine hepatitis virus S (MHV-S), occurrence of a rapidly fatal infection of the CNS is associated with generalized virus dissemination to the bowel, liver, spleen, and other organs (Taguchi et al., 1979; Barthold et al., 1986; Lavi et al., 1984a). 
Histopathology in the CNS includes spongiform lesions within the brain stem. Comparable IN inoculation of neonates with neurotropic A59 and JHMV also results in a wide dissemination into the CNS, respiratory, and vascular endothelium and elsewhere (Barthold and Smith, 1984).

By contrast, A59 and JHM, when given IN to adult mice, induce milder forms of disease. The viruses progress slowly through the olfactory tracts before spreading into the brain and spinal cord (SC) (Barthold et al., 1986). Encephalitis or subacute paralytic symptoms frequently ensue (Lavi et al., 1988; Barthold et a1., 1986). The viscerotropic MHV3 strain of MCV, when inoculated into resistant $\mathrm{A} / \mathrm{JX}$ mice, fails to produce disease symptoms, but nevertheless replicates in liver and brain (Tardieu et al., 1986). Evidently MCVs belonging to the neurotropic or viscerotropic categories possess a more general tropism in the mouse than is indicated by their designation.

After IN infection of mice, virus dissemination and progress of disease have been followed within the CNS and other tissues by means of antibodies and nucleic acid probes. The localization of viral antigen and RNA by means of in situ hybridization in sections has been highly informative. With C57BL/6 mice, in which acute encephalitis develops upon infection with A59 or JHMV, the virus becomes widespread within the cortical gray matter (GM), brain stem, the white matter (WM) tracts in the regions of the optic chiasma, and the SC (Lavi et al., 1988; Perlman et al., 1988, 1989, 1990). A time-course reconstruction of events leads to the conclusion that virus spreads from the trigeminal olfactory locus along anatomically and functionally interconnected neuronal tracts. Dissemination of virus along such neuronal pathways provides a rationale for the speed at which virus can spread toward and within the SC. Virus expression is detectable at the cellular level in neurons and glia, consistent with the histopathology associated with the acute encephalitic or progressive demyelinative diseases caused by A59 and JHM (Perlman et al., 1988; Fleming et al., 1987; Spaan et al., 1988). In the mouse CNS the neurons and oligodendrocytes (OL) are the prominent cell types containing viral RNA and antigen (Lavi et al., 1987), although astrocytes (AS) may also become targets in primary explants. In such cell cultures from neonatal BALB/c or CD.1 mice, both OL and AS are infectable by MCV A59, JHM, and human coronavirus (HCV) OC43 (Wilson et al., 1986; van Berlo et al., 1989; Pearson and Mims, 1985). Likewise, explanted neurons can be productive host cells for A59 and JHMV (Dubois-Dalq et al., 1982; Knobler et al., 1981).

Although the CNS disease process induced in the rat by MCV has many parallels with that observed in mice, notable differences are evident. They include an age-related refractoriness to infection, apparent by the time of weaning (Sorensen et al., 1987a); a requirement for larger inocula, which are usually administered IC to promote efficiency, although neonates can be challenged successfully IN (Hirano et al., 1980); and an association of the CNS and paralytic forms of disease with JHMV but not MHV3, although the latter can produce inapparent infections (Hirano et al., 1980). Again, the progress of infection can be followed in the CNS by antigen and RNA probes, which demonstrate that dissemination occurs in a temporal sequence, culminating with virus spread within the SC (Sorensen et al., 1980, 1984b). The cell types promi- 
nently involved in infection include neurons and OL. In situ hybridization by means of cDNA probes has pinpointed the presence of viral RNA in hippocampal and cerebellar neurons. The virus may remain sequestered in these targets for prolonged periods, even during episodes of subacute, paralytic disease evident in the Wistar Furth (WF) rat model (Sorensen and Dales, 1985; Parham et al., 1986). Rat CNS explants, cultured to promote neuronal survival in vitro, are likewise infectable with JHMV. In such cultures, replication occurs preferentially or exclusively in neurons (Pasick and Dales, 1991). The susceptibility of primary neuron explants to JHMV is consistent with them being primary targets for the development of acute encephalomyelitis (Knobler et al., 1981; Dubois-Dalq et al., 1982; Buchmeier et al.,1984; Sorensen and Dales, 1985; Pasick and Dales, 1991; Matsubara et al., 1991; Zimprich et al., 1991).

Contrary to the dual tropism of JHMV observed with murine cells, in our studies with explanted rat cells, this virus exhibits a reciprocally exclusive tropism for OL compared with MHV3, which infects only type 1 AS (Beushausen and Dales, 1985). This tropism pertains to explants from WF or Wistar Lewis (WL) strains. Our findings were confirmed with Wistar rat glial cultures (van Berlo et al., 1986), although JHMV infection of both OL and AS was detected with glial cultures from WL rat CNS (van Berlo et al., 1989). In this case, the AS lineage (type 1 or 2) was not established.

The inverse tropism to those that we determined has been described in CNS explants from WL rats (Massa et al., 1986). In this study, immunofluorescence labeling indicated selective infection of AS rather than OL, with some modulation in tropism (Massa et al., 1988). These diverse findings on the tropism of JHMV for rat glia have not been reconciled completely, but could be related to the identity of the lineage of infectable AS. The presence of glial acidic fibrillary protein (GFAP) as filament bundles that characterize type 1 AS, also occur, albeit transiently, in the progenitor cell type O2A, from which both OL and type 2 AS differentiate (Raff, 1989; Lillien and Raff, 1990). Since immature, rather than fully differentiated, rat OL appear to be susceptible to JHMV (Beushausen and Dales, 1985), it is likely, as shown by Pasick and Dales (1991), that $\mathrm{GFAP}^{+} \mathrm{O} 2 \mathrm{~A}$ cells become infected and express virus antigen, accounting for the observations of Massa et al. $(1986,1988)$.

In general, the tropism defined in vitro matches the observed distribution of CV infections of the CNS in vivo, and is also consistent with the pathogenesis and disease processes that become evident.

\section{B. Ligand-Receptor Interactions}

The surface component of $\mathrm{CV}$ that attaches to receptors on the host cell is the surface glycoprotein. This molecule possesses features generally associated with peplomers of enveloped viruses (Schmidt et al., 1987). Activation of the fusogenic and penetration activities of $S$ is enhanced by proteolytic cleavage into the subunits $\mathrm{S}_{1}$ and $\mathrm{S}_{2}$ (Schmidt et al., 1987; Luytjes et al., 1987; Frana et al., 1985; Sturman et al., 1985; Stauber et al., 1993; Taguchi, 1993). However, attachment and neutralization by antibodies are not contingent on the proteolytic 
processing of S (Luytjes et al., 1989; Collins et al., 1983). The cell-to-cell spread of infection in the human line Medical Research Council (MRC-C) challenged with HCV 229E (Appleyard and Tisdale, 1985) or the murine cell line $17 \mathrm{Cl}$ I challenged with A59 (Sturman et al., 1985; Frana et al., 1985), requires the activation of $S$ by a cellular protease that is inhibited by agents such as leupeptin (Appleyard and Tisdale, 1985). Also, virus dissemination is not absolutely contingent on the formation of syncytia, even after $S$ has been processed into $S_{1} /$ $\mathrm{S}_{2}$. Thus, MHV A59 is highly fusogenic for $17 \mathrm{Cl} \mathrm{I}$ and $\mathrm{L}$ cells, but in contrast to MHV3 and JHMV is nonfusogenic in vivo or for explanted rodent glial cells (Lucas et al., 1977; Sturman et al., 1985; Frana et al., 1985; Lavi et al., 1987; Wilson and Dales, 1988). Differences in syncytiogenic activity among CVs remain unexplained.

The receptor specificity for CV has also been studied as a determinant of tropism. In one system using rat glial cultures, one can demonstrate an unambiguous tropism of JHMV for OL and MHV3 for AS, but there is no difference in the binding efficiency of labeled inoculum particles of either virus to either cell type (Beushausen and Dales, 1985). With continuous cell lines such as the rat RN2-2 Schwannoma, which is infectable by JHMV but not by MHV3, both virus types likewise become attached equally well (Lucas et al., 1977, 1978). In the case of the C6 rat astrocytoma cell line, which is resistant to infection by both viruses, receptors for JHMV, MHV3, and other MCV strains are present (van Dinter and Flintoff, 1987; Flintoff and van Dinter, 1989; Kooi et al., 1988). In the case of sublines derived from the prototype $\mathrm{L}$ strain murine line, the more restrictive subline LM-K can absorb A59 virus as efficiently as the highly permissive L2 cell (Kooi et al., 1988). A similar situation is found with cells from SJL/J mice, which are highly resistant to JHMV but not to MHV3. Thus, both viruses can be adsorbed with the same efficiency to OL and AS of SJL/J mice and to OL and AS of permissive BALB/c and CD.1 mice (Wilson et al., 1986).

A presumed absence of receptors for A59 on SJL/J hepatocytes and enterocytes, which was assumed to account for differences in resistance of SJL/J mice compared to susceptible BALB/c mice (Boyle et al., 1987), also can now be explained. The MHV receptor is a $110-120-\mathrm{kDa}$ G-P, a member of the carcinoembryonic antigen family (Williams et al., 1991). Although this G-P is expressed on SJL/J cells, its form is modified (Yokomori and Lai, 1992), presumably affecting the efficiency of JHMV replication. Whatever the deficiency of receptors for JHMV and A59 might be in SJL/J mice, the resistance of neurons and glia from these mice is due to a defect in cell-cell virus spread rather than an absence of receptors per se (Wilson and Dales, 1988; Pasick et al., 1992). Virus dissemination may involve a deficiency in the processing of $S$ because a more fusogenic JHMV variant ATf11, isolated from rat SC (Morris et al., 1989), is not restricted in SJL/J glial cells (Pasick et al., 1992).

The identification of a hemagglutinin esterase (HE) glycoprotein component in BCV (Vlasak et al., 1988) drew attention to the possible function of HE during early interactions with host cells. By sequence comparison, HE shows evolutionary relatedness with the influenza type $\mathrm{C}$ hemagglutinin $\mathrm{H}_{1}$ subunit (Kienzle et al., 1990). The esterase of HE has receptor-binding activity and 
inactivates receptors on erythrocytes by hydrolyzing O-linked acetylsialic acid (Schultze et al., 1991). Since this reaction and virus entry are both blocked with diisopropyl fluorophosphate (Vlasak et al., 1988), it is presumed that HE acts in a manner similar to that of a receptor-destroying enzyme of type $C$ influenza virus (Kienzle et al., 1990). Evidently the esterase is not essential for infectivity because it is absent from MCV A59 and some MCV JHM strains (Parker et al., 1990). Some of the roles suggested for HE are: as a determinant of tropism or virulence in the CNS; as an additional ligand for binding of cell targets; or for facilitating the penetration of inoculum virus (reviewed in Parker et al., 1990; Vlasak et al., 1988).

\section{Penetration}

An electron microscopic examination of the interaction between surfaces covering the microvilli in calf intestine inoculated with the calf diarrhea $\mathrm{CV}$ was interpreted as showing fusion between the virus envelope and plasma membrane on microvilli (Doughri et al., 1976). Studies on cells in culture, using biochemical and electron microscopic methods, suggested that MCV initiates an infection following sequestration or viropexis of the inoculum (reviewed in Krzystyniak and Dupuy, 1984). The inhibition of early stages of A59 or MHV3 infection, including the eclipse phase (Mizzen et al., 1985), in L2 cells treated with agents such as $\mathrm{NH}_{4} \mathrm{Cl}$ and chloroquine (Krzystyniak and Dupuy, 1984), also supports a requirement for engulfment as an obligatory function for initiating infection. More recent unpublished data from our laboratories indicate that $\mathrm{NH}_{4} \mathrm{Cl}$ only marginally inhibits the early stages of MHV infection, implying that penetration and release of the genome occurs in "early" endosomes containing a neutral or only slightly acidic milieu due to their intracellular location close to the cell surface. (Schmid et al., 1989).

Studies of penetration by JHM, A59, and MHV3 into continuous neural and nonneural cell lines suggest that interactions with the host may vary. The virions that are absorbed onto and sequestered by $\mathrm{C} 6$ astrocytoma cells do not become eclipsed (van Dinter and Flintoff, 1987), due to an unidentified defect that can be circumvented by inducing fusion between viral and cell membranes by means of polyethylene glycol (PEG). PEG by itself does not enhance the infectiousness of permissive cells, among them L, RN2-2 Schwannoma, and HTC hepatoma lines. The failure of a "low $\mathrm{pH}$ shock" to promote infectability of MCV in the manner observed with vesicular stomatitis virus (VSV) and A-type influenza viruses also argues against involvement of an acidic endosomal compartment in the penetration sequence (Flintoff and van Dinter, 1989). Host control over virus penetration, examined by means of cell-cell hybrids between the resistant C6 and either partially or fully permissive cell lines showed that $\mathrm{C} 6 \times \mathrm{L} 2$ and $\mathrm{RN}-2 \times \mathrm{L} 2$ cell lines could be infected without the use of PEG (Flintoff and van Dinter, 1989; Coulter-Mackie et al., 1984). However, these permissive cell hybrids retain the phenotype of the parent that resists extensive syncytia formation. This demonstrates that penetration and MCVinduced cell-cell fusion are controlled independently. 


\section{Uncoating and Initiation of Genome Functions}

Although the ssRNA genome penetrates from inoculum virions into the host within a helical coat of $\mathrm{N}$ protein (Davies et al., 1981), the infectivity of the naked genomic RNA (Siddell et al., 1982) implies that, in the normal course of penetration, the uncoating step involves dissociation of $\mathrm{N}$ from the RNA. The nascent $\mathrm{N}$ polypeptide of JHMV has a molecular weight of $50 \mathrm{kDa}$ which increases to $56 \mathrm{kDa}$ upon phosphorylation. The $56-\mathrm{kDa}$ phosphorylated form of $\mathrm{N}$ exists in virions (Armstrong et al., 1983; Wilbur et al., 1986; Siddell et al., 1981). From sequence data on N (Armstrong et al., 1983; Skinner and Siddell, 1983) and other evidence (Wilbur et al., 1986), one can deduce that $\mathrm{N}$ has two to four, or perhaps more, potential sites for phosphorylation, a modification effected prior to virion assembly by either cellular kinases (PK) or a MCVspecified PK. In a converse sequence of events taking place during penetration, the molecular weight of $\mathrm{N}$ is reduced initially from 56 to $50 \mathrm{kDa}$, then further breakdown into smaller molecular weight polypeptide fragments occurs (Beushausen et al., 1987). Conceivably, dephosphorylation of $\mathrm{N}$ promotes the uncoating process, as documented for retroviruses (Beushausen et al., 1987; Mohandas and Dales, 1991).

Our demonstration of the existence, in an endosome fraction of a cellular phosphoprotein phosphatase [(PPPase) belonging to the neutral type 1 class of enzyme, unpublished], with a high specificity for $\mathrm{N}$ (Mohandas and Dales, 1990), is consistent with the view that uncoating may either commence or proceed to completion in "early" endosomes and/or close to the cell surface. In this context, it is worth mentioning that endosomal PPPases of a type similar to that acting on $\mathrm{N}$ have been recognized in clathrin-coated vesicles, where they may catalyze the rupturing of polymeric clathrin protein cages and facilitate movement of the freed endosomes and fusion of the endosomal membrane with other membrane compartments (Pauloin et al., 1988; Greene and Eisenberg, 1988; Loeb et al., 1989).

\section{E. Effect on Cellular Protein Synthesis}

Viruses have developed diverse strategies to ensure the translation of virusspecific mRNAs in the infected cell. MCV gives rise to mRNAs that share the structural characteristics of most eurkaryotic mRNAs, such as the presence of 5' terminal caps (Lai et al., 1982) and 3' poly A tails (Cheley et al., 1981; Cheley and Anderson, 1981). It appears unlikely, therefore, that translational control in $\mathrm{MCV}$ infection is mediated by the alteration of host initiation factors such as occurs, for example, in poliovirus infection and results in the selective translation of structurally distinct (e.g., uncapped) mRNAs (Kaufman et al., 1976; Trachsel et al., 1980).

At high multiplicities of infection, MCV inhibits host protein synthesis in certain cell lines. In mouse L2 fibroblasts, infection results in a decline in total protein synthesis to about $7 \%$ of controls. This overall decrease is likely due to a partial block of translation at the initiation stage, as indicated by an 
increase in free $80 \mathrm{~S}$ ribosomes. There is also a shift in size from heavier to lighter polysomes, reflecting increased competition by a greater number of shorter mRNAs for a limited quantity of available ribosomes. The overall total poly $(\mathrm{A}){ }^{+}$RNA content of the infected cell is increased approximately threefold by $6 \mathrm{hr}$ postinfection, as a result of the synthesis and accumulation of viral mRNA. Most interestingly, by this time, and later in infection, cellular mRNA transcripts disappear, apparently due to a degradative mechanism (Hilton et al., 1986).

Previously, virus-induced hydrolysis of host mRNA had been noted after infection with complex DNA viruses, such as herpes simplex (Nishioka and Silverstein, 1978) and vaccinia (Rice and Roberts, 1983), and with influenza, an RNA virus. In the case of influenza, breakdown of host mRNA is a consequence of the unique mode of transcapping, i.e., the capture of host-derived 5'-caps (Bouloy et al., 1980; Plotch et al., 1981). Most other RNA viruses studied to date, however, appear to effect translational controls by nondegradative mechanisms (Fernandez-Munoz and Darnell, 1976; Gallwitz et al., 1977; Lodish and Porter, 1981). Evidence has also been presented suggesting that during infections with some viruses, including adenovirus (Lazaridis et al., 1988) and La Crosse virus (Raju and Kolakofsky, 1988), viral functions are expressed that affect the stability of cellular or viral mRNAs.

It is intriguing to speculate that the mechanism of RNA degradation connected with MCV infection (Hilton et al., 1986) is related to the unique replication strategy of coronavirus. It has been suggested that the synthesis of CV subgenomic mRNAs may involve nucleolytic trimming (Lai, 1986). Although this type of nucleolytic activity has yet to be identified, if present, such a MCVinduced nuclease could also presumably recognize as a substrate cleavage sites in cellular mRNAs, thereby accelerating their hydrolysis by host degradative mechanisms.

Another obvious cell-killing function of MCV infection is the inhibition of host translation (e.g., Marvaldi et al., 1977). Differences among host cells in their susceptibility to MCV-mediated translational control could be manifested in the cytopathology that occurs and also determine whether the outcome is an acute or persistent infection.

\section{F. Effects on Cellular Membranes}

The unique sites of $\mathrm{CV}$ assembly by budding from smooth endoplasmic reticulum membranes, recognized by electron microscopy (Massalski et al., 1982; Barthold and Smith, 1984; Pasick et al., 1994; Krijnse-Locker et al., 1994; Klumperman et al., 1994), has not yet been explained. Earlier, it was thought that the $M$ protein had an important role in organizing the assembly of virion envelopes on these internal membranes, mainly because this protein has signals for retention in the Golgi (Swift and Machamer, 1991). Recently, however, it has become apparent that the Golgi compartment is beyond the site of budding (Klumperman et al., 1994). One reason suggested for $M$ being anchored and retained on internal membranes is the preferential O-linked glycosylation 
(Rottier et al., 1984; Niemann and Klenk, 1981; Niemann et al., 1984). In contrast, the $\mathrm{S}$ protein, which possesses $\mathrm{N}$-linked carbohydrates, behaves like the usual peplomer G-P of viruses budding from the cell surface. Thus, although $\mathrm{S}$ attaches to the formative $\mathrm{CV}$ envelopes within the budding compartment, it can also migrate independently to the plasma membrane where it accumulates and can express fusogenic activity (Rottier et al., 1984; Niemann et al., 1984).

Electron microscopic examination of MCV-infected cells has revealed apparent distensions or amplification of intracellular membranes that may be derived from smooth endoplasmic reticulum (David-Ferreira and Manaker, 1965; Massalski et al., 1982; Dubois-Dalq et al., 1982; van Berlo et al., 1986; Tooze et al., 1984). It has been speculated that such membrane proliferation or reorganization may reflect a cellular response to the removal of membrane lipid as it becomes incorporated into virion envelopes (Tooze et al., 1984). This explanation seems to be unlikely since membrane proliferation has been observed during infection with a temperature-sensitive (ts) mutant of $\mathrm{MCV}$, when virion assembly was interrupted (van Berlo et al., 1986). The stimulation of membrane proliferation and lipid biosynthesis resulting from cytopathology have also been observed following infections with other agents, among them nonenveloped polio- and mengovirus (Penman, 1965; Amako and Dales, 1967.

A very obvious manifestation of virus-cell membrane interactions occurring within the replication cycle of $\mathrm{MCV}$ is membrane fusion. Fusion occurs both early during virion entry and uncoating and later when syncytiogenesis is evident. The control of cell-cell fusion is closely related to events that contribute to the establishment of a cytolytic versus an attenuated or persistent infection (Kooi et al., 1988; Mizzen et al., 1983, 1985, 1987b).

The $S$ proteint is a key mediator for both cell fusion and pathogenesis. Within the infected CNS, differences among cell types have been noted in relation to virus-induced cell fusion (Sorensen et al., 1980; Dubois-Dalcq et al., 1982; Buchmeier et al., 1984). By inducing cell-cell fusion from within, MCV may facilitate both dissemination of virus and maintenance of persistent infections, as demonstrated in the presence of neutralizing antibodies added to the medium (Buchmeier et al., 1984; Sorensen et al., 1984a; Stohlman and Weiner, 1978). In cultures, such as the Cl-1 line, which is relatively resistant to JHMVmediated syncytiogenesis, individual cells may survive a cytolytic, acute infection, thereby maintaining a state of virus persistence (Mizzen et al., 1983).

The resistance of murine cells to various strains of MCV appears to be under the control of a single autosomal, recessive gene (Bang and Warwick, 1960; Virelizier and Allison, 1976; Stohlman and Frelinger, 1978). Concomitantly, the complete or partial genetic resistance to disease observed with some strains of mice is inherent in explanted macrophages, hepatocytes, fibroblasts, and other cell types. The infection of cells from such mice results in either an abortive (Virelizier and Allison, 1976) or limited infection, with reduced cytopathology (MacNaughton and Patterson, 1980; Arnheiter et al., 1982; Lamontagne and Dupuy, 1984a). Although cultured macrophages, OL and AS from SJL/ J mice, which are resistant to JHMV as primary targets of infection, can support MCV replication, the cell-cell spread of virus due to a fusion-dependent mechanism is restricted (Knobler et al., 1984). Some deficiency of an SJL/J cell protease 
was suggested as an explanation for the absence of cell-cell spread of virus. In fact, studies on the spontaneous acquisition of resistance by $\mathrm{L} 2$ cell mutants, selected for the survival of a usually lethal MCV infection, demonstrate that partial resistance to infection and to S-mediated syncytia formation are comutable characteristics of the host cell (Daya et al., 1989). Homeostatic control of fatty acid and cholesterol metabolism has been shown to be another important regulator of virus-mediated cell fusion both in vivo and in vitro (Cervin and Anderson, 1991).

It has been assumed that differences in the infectability and susceptibility of cells to MCV-mediated fusion are correlated (Mizzen et al., 1983, 1987b), and depend on proteolytic activation of $S$, presumably involving a host cell protease (Frana et al., 1985). Quantitative cleavage of $S$ is, however, not necessary for cell-cell fusion, and there is no strict correlation between the proteolysis of $S$ and the extent of cell fusion (Frana et al., 1985), as indicated when S was mutated in the cleavage signal and expressed independently by vaccinia recombinants (Stauber et al., 1993; Taguchi, 1993). Also, one class of fusion (from within) defective MCV mutant, which possesses a single mutation within the cleavage signal of $S$, has been isolated from persistently infected glial cultures (Gombold et al., 1993). It is possible that uncleaved S protein is fusogenic, but that fusogenicity is enhanced upon proteolytic cleavage.

CV-induced membrane fusion and the severity of infection are also influenced by host cell membrane lipid composition (Daya et al., 1988), particularly the cholesterol content (Daya et al., 1988). Conceivably there may be a specific interaction between peptide sequences of the $\mathrm{S}$ protein and cholesterol, in a manner similar to that observed with Sendai virus F protein (Asano and Asano, 1988). Another modulation of MCV infection by cholesterol may pertain to the inhibition of Kupffer cell function during in vivo infection (Pereira et al., 1987). The observed association of the MCV N protein with cellular membranes may be another example of lipid-dependent events during replication. $\mathbf{N}$ is synthesized on free polysomes but associates posttranslationally with membranes, possibly as a result of its phosphorylation (Stohlman et al., 1983). Since N binds the viral M protein (Sturman et al., 1980) and the M protein is found in association with smooth endoplasmic reticulum (ER) membranes (Rottier and Rose, 1987), the membrane attachment may be mediated by the $M$. Nevertheless, $N$ protein is able to associate with cellular membranes in the absence of $\mathbf{M}$ (Anderson and Wong, 1993), raising the possibility that the components involved are certain membrane phospholipids (Anderson and Wong, 1993). Interestingly, the ability of $\mathrm{N}$ to bind both membrane phospholipids and nucleic acid is perhaps analogous to that shown by certain bacterial DNA-binding proteins such as DnaA (Sekimizu and Kornberg, 1988) and RecA (Krishna and van de Sande, 1990). The possibility, therefore, arises that an association of $\mathrm{N}$ with viral RNA is influenced by competitive binding to membrane phospholipids.

The involvement of the cytoskeleton in a number of MCV infections has also been investigated. Treatment of L2 fibroblasts with colchicine or cytochalasin B, drugs that disorganize microtubules and actin filaments, alters cell shape without affecting syncytiogenesis or the acute cytopathology (Daya et al., 1988). By contrast, in peritoneal macrophages exposed to cytochalasin B, the 
infection is changed from an acute to a persistent type (Mallucci and Edwards, 1982). Quite possibly, the cytoskeleton plays a role in regulating MCV assembly and cytopathology, involving membranes that may vary in a cell-dependent manner according to differences in the organization of the cytoskeleton. The close association of $\mathrm{N}$ of JHMV with microtubules in neurites of cultured neurons, recently recognized by Pasick et al., (1994), was explained in terms of a specific binding by $\mathrm{N}$, via a region of the protein that has a close sequence homology to the microtubule-binding site of the cytoskeletal protein tau.

As mentioned above, the presence of $S$ at the cell surface is related to cell fusion (Collins et al., 1982). However, it may also affect control of plasma membrane permeability, as evidenced by an influx of sodium ions (Mizzen et al., 1987a). This occurs during both acute and persistent infections (Macintyre et al., 1989). However, in contrast to certain other virus infections (Carrasco and Smith, 1976), there is evidence that in MCV-infected cells an elevated intracellular sodium ion concentration affects the regulation of translational control (Mizzen et al., 1987a). One should not exclude the possibility that altered membrane permeability can affect other aspects of viral cytopathology.

\section{G. Factors Related to Latency and Persistence}

Infection of the CNS can establish a very prolonged state of CV latency or persistence. Whether the animal remains asymptomatic or undergoes a lateonset progressive paralytic disease with demyelination, virus expression in the form of RNA, antigen, or infectious particles may continue for prolonged periods in mice (Pickel et al., 1981; Lavi et al., 1984a,b, 1987; Perlman et al., 1988; Knobler et al., 1981) or rats (Wege et al., 1983, 1984; Sorensen et al., 1984b; Sorensen and Dales, 1985). Persistent infections are readily established in explanted primary neural cells (Dubois-Dalq et al., 1982; Beushausen and Dales, 1985; Wilson et al., 1986; Pearson and Mims, 1985; van Berlo et al., 1989; Lavi et al., 1987) and continuous cell lines of neural and nonneural derivation (Flintoff and van Dinter, 1989; van Dinter and Flintoff, 1987; Coulter-Mackie et al., 1984, 1985; Lucas et al., 1977; 1978; Collins and Sorensen, 1986; Leibowitz et al., 1984). Evidently, conditions prevail in the CNS of postweanling and adult rodents, as well as in neural cells in culture, which favor maintenance of the state of persistence. Analogous observations have been documented for other neurotropic RNA viruses such as measles virus (Miller and Carrigan, 1982; Yoshikawa and Yamanouchi, 1984), canine distemper virus (Pearce-Kelling et al., 1990; Zurbriggen et al., 1987), rubella virus (van Alstyne and Paty, 1983), picorna viruses (Rodriguez et al., 1990), and alpha viruses (Bruce et al., 1984). A common feature linking MCV with all of the above agents is an initial low rate of replication associated with limited cytopathology. Following a period of adaptation, during which, perhaps, variants are selected and maintained, the infectious process may remain unchanged or switch into a more acute or more attenuated mode (Taguchi and Siddell, 1985) or replication may be entirely suppressed (Collins and Sorensen, 1986). The exceptionally high efficiency of MCV genetic recombination creates numerous variants (Lai et al., 1985; Ma- 
kino and Lai, 1989|, a phenomenon that can account, at least partially, for the varying types of infection encountered, as discussed in Section IV.

The repeated passage of JHMV in murine fibroblastic DBT cell lines generates defective-interfering (DI) particles in which genomes are shortened by deletions (Makino et al., 1984, 1985). In a high multiplicity of infection, DIs interfere with the transcription of all mRNAs species with the exception of mRNA7, coding for $\mathrm{N}$. There is no substantial evidence linking DIs with CV infections of the CNS or neural cell explants (Taguchi and Siddell, 1985).

A regular feature of MCV persistence in continuous cell lines, not exclusively of the neural type, is a wavelike, cyclical production of infectious particles (Lucas et al., 1977, 1978; Coulter-Mackie et al., 1984, 1985). Such periodicity in virus titer also has been reported for measles and rabies viruses (reviewed in Lucas et al., 1978) but is not evident during MCV infections of primary neural cell cultures (Beushausen and Dales, 1985; Wilson et al., 1986). With rabies virus, the rise and fall of titers was explained as due to reciprocal periodic development of an antiviral state related to the autocrine activity of interferon (IFN) (reviewed in Coulter-Mackie et al., 1985). During persistent infection of porcine alveolar macrophages by transmissible gastroenteritis virus (TGEV) of pigs, an induction of $\alpha$-IFN was observed (Laude et al., 1984). By contrast, our extensive, detailed search for the induction of IFN during a cyclical rise and fall of JHMV titers from RN2-2 Schwannoma cells failed to detect the presence of this lymphokine, although these host cells have the capacity to acquire an antiviral state and make IFN when appropriately induced with reovirus (Coulter-Mackie et al., 1985). Likewise, persistent infections of mouse neuroblastoma C1300 cells with JHMV (Leibowitz et al., 1984) and human glioblastoma U-87 HG cells infected with HCV OC43 (Collins and Sorensen, 1986) do not evoke the production of IFN, demonstrating that in these systems IFN or the antiviral state are not required to maintain persistence. The effectiveness of IFN as a protective factor may also depend on the MCV strain involved. Thus, with DBT cells, which become productively infected, $\alpha$-IFN fails to arrest replication or the development of cytopathology when the highly virulent MHV-2 is used, whereas IFN treatment can abrogate both virus production and cell killing when MHV-S or JHMV are used as infectious agents (Taguchi and Siddell, 1985).

Another reversible cellular response to $\mathrm{MCV}$ infections of primary neural cell explants and continuous cell lines is the suppression of persistent virus production that occurs on a shift up of the ambient temperature from a permissive $32-33^{\circ} \mathrm{C}$ to the restrictive $39-40^{\circ} \mathrm{C}$ (Lucas et al., 1977, 1978; CoulterMackie et al., 1984, 1985; Sorensen et al., 1984a). The MHV3 and JHMV progeny generated during permissive infection of $\mathrm{L} 2$ cells do not acquire or possess a thermosensitive or thermolabile phenotype during passage through lymphocytic (Lamontagne and Dupuy, 1984b) or neural cells (Lucas et al., 1978; Leibowitz et al., 1984). Similar results were obtained with measles virus (Lucas et al., 1978). This implies that latency at elevated temperature is due to some controlling factor(s) in the host cells per se that is not IFN (Coulter-Mackie $e t$ al., 1985; Leibowitz et al., 1984). By contrast, replication of HCV OC43 in the UH87 HG line generates thermosensitive variants, so that during restriction at 
high temperature persistent or latent OC43 virus is rapidly eliminated and cells are "cured" (Collins and Sorensen, 1986).

A detailed study of latency was undertaken using the RN2-2 cells infected with JHMV (Coulter-Mackie et al., 1985). The virus formed during persistent infections at $33^{\circ} \mathrm{C}$ is not temperature sensitive. Within $24 \mathrm{hr}$ after shift up to $39^{\circ} \mathrm{C}$, replication is arrested, but the latent genomes are maintained in the host cell for prolonged periods and gene expression, measured as translation into $\mathrm{N}$ protein, can be detected for several days. If the latently infected cells, which continue to grow and divide at $39^{\circ} \mathrm{C}$, are returned to the permissive temperature following 2 to 3 weeks, virus production slowly resumes. Analyses made by following a time-course in the decline of infectious centers yielded data compatible with a probability model that predicts that due to continual segregation of the limited number of latent JHMV genomes among daughter cells, the virus genome is eventually lost by a dilution effect.

\section{RELATIONSHIP BETWEEN DEVELOPMENT AND DIFFERENTIATION OF THE CENTRAL NERVOUS SYSTEM AND THE DISEASE PROCESS}

\section{A. Characteristics of the Cells Involved}

Under normal circumstances, the suceptibility of rats to CV-induced disease extends only to the time of weaning (Sorensen et al., 1980), whereas mice remain susceptible to challenge into adulthood. The idea that the tropism of CV for specific cells in the CNS can explain the basis of encephalitic and demyelinative paralytic cells in the CNS has already been considered in Section II. In the rat model, a temporal coincidence between the completion of myelination and the onset of resistance to JHMV drew our attention to OL maturation as a possible determinant of resistance to JHMV-induced demyelinating disease (Beushausen and Dales, 1985; Wilson et al., 1986; Beushausen et al., 1987). Also, the availability of methods for reproducibly culturing cells explanted from the CNS now makes it possible to follow the process of differentiation and infection among defined types of neural cells.

Soon after explantation from the brain, a mixture of neurons, cells of glial lineage, and other elements are present in culture. The composition of the nutrient media, including a serum supplement, can profoundly affect the cell types that remain during prolonged cultivation and the cell type selection (Fabre et al., 1985; Gard and Pfeiffer, 1989; Muraoka and Takahashi, 1989; Koper et al., 1984). Thus, with respect to glial cultures, type 1 AS, identified by the presence of GFAP, and the O2A bipotential OL and type 2 AS progenitor cells, which have receptors for monoclonal antibody (MAb) A2B5 (and hence are designated as $\mathrm{A} 2 \mathrm{~B}^{+}{ }^{+}$(Raff, 1989), are the most numerous elements when neonatal cortex is explanted into nutrient medium with added serum (Beushausen and Dales, 1985; Koper et al., 1984). Moreover, the progression of O2A cells into AS or OL lineages, respectively, can be reconstructed by following the progeny of individual cells in rat optic nerve cultures (Raff, 1989). These elegant analyses 
demonstrated that, even after their separation from the CNS, glial cells are endowed with a predetermined developmental "time-clock" that probably simulates the program existing in vivo. The aquisition of GFAP by daughters of O2A parents identifies them as type 2 AS. Daughters of O2A expressing myelin basic protein (MBP), CNPase activity, and GalC on their surfaces are destined to become OL.

The appearance of the mature OL phenotype is more rapid if cells are sparsely distributed in culture dishes (Aloisi et al., 1988) or are grown on poly L lysine, which promotes tight adherence to the substrate. Factors promoting differentiation favor the onset of resistance to JHMV infection (Beushausen and Dales, 1985). Conversion from the O2A into 2AS or OL types is also influenced by growth factors such as basic fibroblastic growth factor (bFGF) and plateletderived growth factor (PDGF) (McKinnon et al., 1990; Bögler et al., 1990). For example, PDGF, secreted by type 1 AS, promotes the appearance of OL (Raff, 1989; Levine, 1989). When recently established cultures are switched from a serum containing medium to a defined, serumless medium, the survival of neurons is promoted and an alteration of $\mathrm{A} 2 \mathrm{~B} 5^{+}$cells into differentiated $\mathrm{OL}$ is enhanced (Raff, 1989; Levine 1989; Koper et al., 1984). This suggests that there are factors in serum that help to maintain O2A cells but may inhibit the survival of neurons. Interactions between neurons and OL are indicated by the myelination of neuronal processes in vitro, albeit of a rudimentary type (Muraoka and Takahashi, 1989; Pasick and Dales, 1991). Myelin elaboration in cultures of OL also has been reported in the absence of neurons, implying that axons are not an essential stimulus for triggering myelin formation (Fabre et al., 1985)

\section{B. The Infectious Process in Differentiating OL}

If kept for several days, cultures of mixed rat glial cell types contain tightly adherent type $1 \mathrm{AS}$ on the bottom and more loosely attached O2A and OL above the subjacent AS layer. The mixed glia culture can be infected persistently with JHMV and MHV3. After shaking off the top cell layer, type 1 AS are infectable exclusively by MHV3. After replanting, the shaken cells can support only JHMV replication (Beushausen and Dales, 1985; Wilson et al., 1986). Shaken cells, when kept in culture for 2 to 3 weeks, become resistant to JHMV and switch from $\mathrm{A} 2 \mathrm{~B} 55^{+}$into the mature OL phenotype. Shaken cells can be induced to differentiate more rapidly and resist JHMV infection by pretreatment with $\mathrm{N}_{6}, \mathrm{O}_{2}$-dibutyryl 3':5' cAMP (dbcAMP) (see Table I). By contrast, AS treated with this metabolite continue to produce abundant quantities of MHV3. Cultured neurons exposed in the same manner to dbcAMP can be infected persistently and produce high titers of JHMV (Pasick and Dales, 1991). With other neurotropic viruses quite different effects of dbcAMP are observed. Infection of AS with rubella virus becomes latent, but it is induced to a productive infection by dbcAMP (van Alstyne and Paty, 1983). In contrast, infection of neuronal and other cell lines with measles virus is reversibly inhibited by dbcAMP, possibly at a late stage in virus expression (Miller and Carrigan, 1982; Yoshikawa and 
TABLE I. Effect of dbcAMP on the Replication of JHMV in Primary Oligodendrocytes ${ }^{a}$

\begin{tabular}{lccccccc}
\hline & \multicolumn{7}{c}{ Days postinfection } \\
\cline { 2 - 8 } Treatment of culture & 2 & 3 & 4 & 6 & 8 & 12 & 14 \\
\hline Control & 13 & 46.8 & 55 & 38.8 & 720 & 31 & 20 \\
$1 \mathrm{mM}$ postinfection & 33.4 & $100^{b}$ & 15.5 & 100 & 500 & 26 & 30 \\
$1 \mathrm{mM} \mathrm{48} \mathrm{hr} \mathrm{before} \mathrm{infection}$ & 0 & 0 & 0 & 0 & 0 & 0 & 0 \\
$1 \mathrm{mM} \mathrm{48} \mathrm{hr} \mathrm{before} \mathrm{infection}$ & 0 & $0^{c}$ & 0 & 0 & 0 & 0 & 0 \\
\hline
\end{tabular}

NOTE: All titers expressed $\times 10^{2} \mathrm{PFU} / \mathrm{ml}$ multiplicity of infection $0.5-1.0 /$ cell in each case. ${ }^{a}$ Adapted from Beushausen and Dales (1985).

$b \mathrm{dbc} A M P$ added.

${ }^{c} \mathrm{dbcAMP}$ removed.

Yamanouchi, 1984). These observations indicate that dbcAMP effects may be different for each type of neural cell and virus tested, even among MCV strains.

The resistance to JHMV in cells belonging to the OL lineage can be affected by metabolites other than dbcAMP, as long as they can act to elevate intracellular concentrations of cAMP (Beushausen et al., 1987) (Fig. 1). These data indicate that adenylate cyclase metabolism is generally involved, perhaps through the cAMP-dependent protein kinase(s) (PK). Oligodendrocytes, like brain tissue generally, constitutively possess the PK II activity but lack PK I. A striking effect of induced OL differentiation is a tenfold increase in the amount of PK I regulatory subunit RI despite the absence of constitutive PK I enzyme from OL (Beushausen et al., 1987). Infection by MCV is arrested in mature OL at some stage after internalization of the inoculum but prior to the initiation of genome expression. The critical step affected by dbcAMP treatment, or by the normal differentiation process, could be the uncoating step, defined here as the separation of genome RNA from a phosphorylated form of $\mathrm{N}$ constituting the helical capsid (Beushausen et al., 1987). Evidence has been obtained showing that dephosphorylation of $\mathrm{N}$ is followed by its proteolytic breakdown. This step, which likely occurs after attachment and uptake, as illustrated in Fig. 2, may be catalyzed by a neutral PPPase concentrated in endosomes (Beushausen et al., 1987; Mohandas and Dales, 1991). A PPPase that is highly specific for $\mathrm{N}$ occurs in rat brain tissue, OL ROC-1 cells (a hybrid cell line created from OL $\times$ C6), and in the highly permissive L2 cell (Mohandas and Dales, 1990). It is remarkable that the $\mathrm{N}$-specific, endosomal PPPase activity is inhibited by the addition of RI to the reaction, providing evidence for a putative mechanism involved in blocking JHMV infection in OL (Wilson et al., 1990). As might be expected from these findings, the block to the process of MCV uncoating, relating to the dephosphorylation of $\mathrm{N}$ in mature $\mathrm{OL}$, can be circumvented by transfection with genomic JHMV RNA (K. Kalicharran and S. Dales, unpublished data).

\section{Immunity as a Factor Regulating Pathogenesis and Disease}

Both cellular and humoral components of immunity modulate the disease process due to CNS infections by MCV. Protection against acute, lethal enceph- 

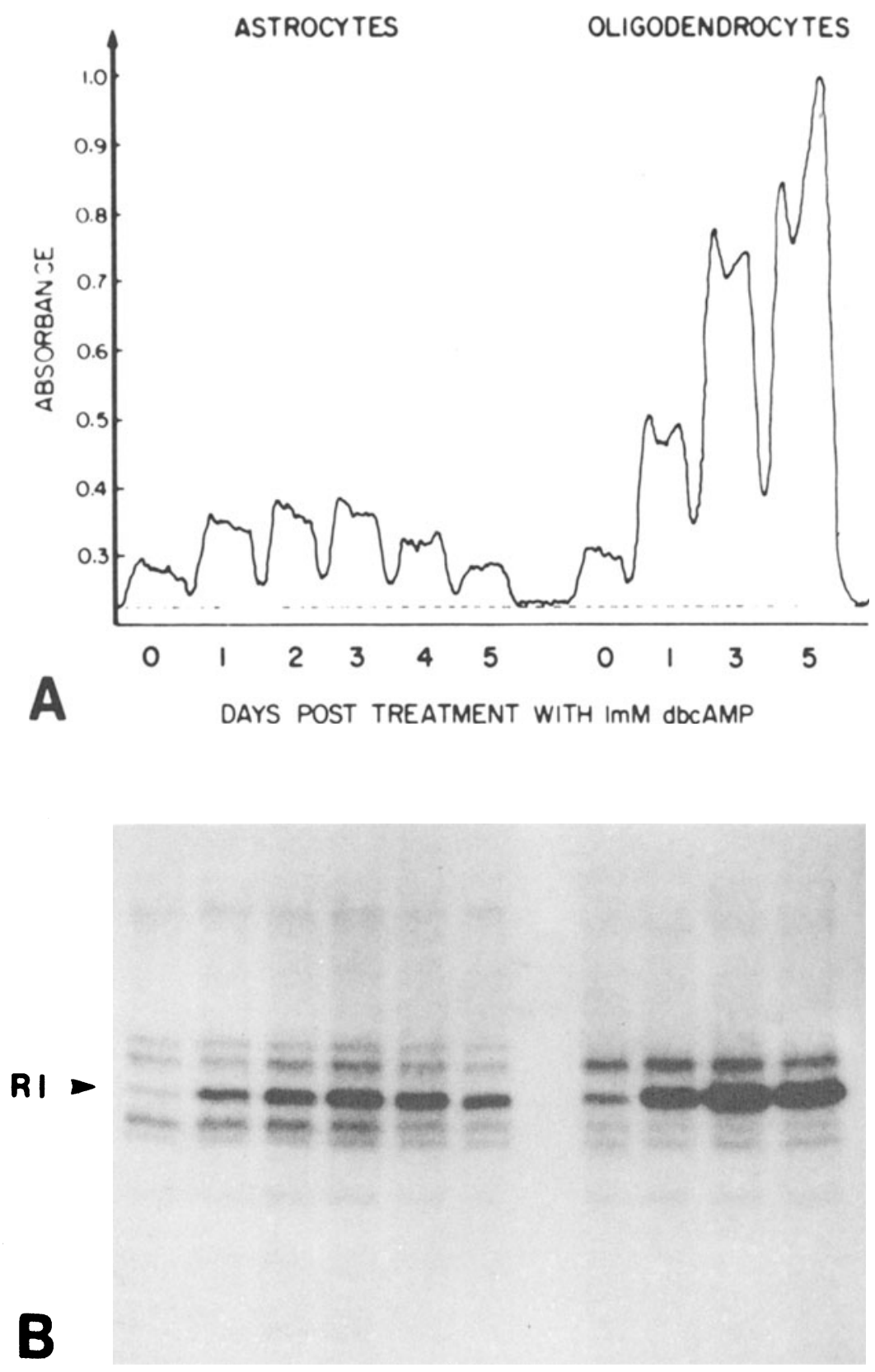

FIGURE 1. Modulation of R I and R II in primary rat astrocytes and oligodendrocytes during treatment with $1 \mathrm{mM}$ dbcAMP. The concentrations of the regulatory subunits in cytosol $(100,000 \times$ g) fractions from astrocytes and oligodendrocytes were determined by binding of 8 -azido- $\left.{ }^{32} \mathrm{P}\right]$ cAMP. A densitometer tracing (A) made from an autoradiogram (B), obtained after $10 \%$ sodium dodecyl sulfate-polyacrylamide gel electrophoresis, enabled a comparison of the time-related changes in the R I regulatory subunit. Absorbance units have been normalized to the band of greatest density (oligodendrocytes, 5 days posttreatment). (From Beushausen et al., 1987.) 


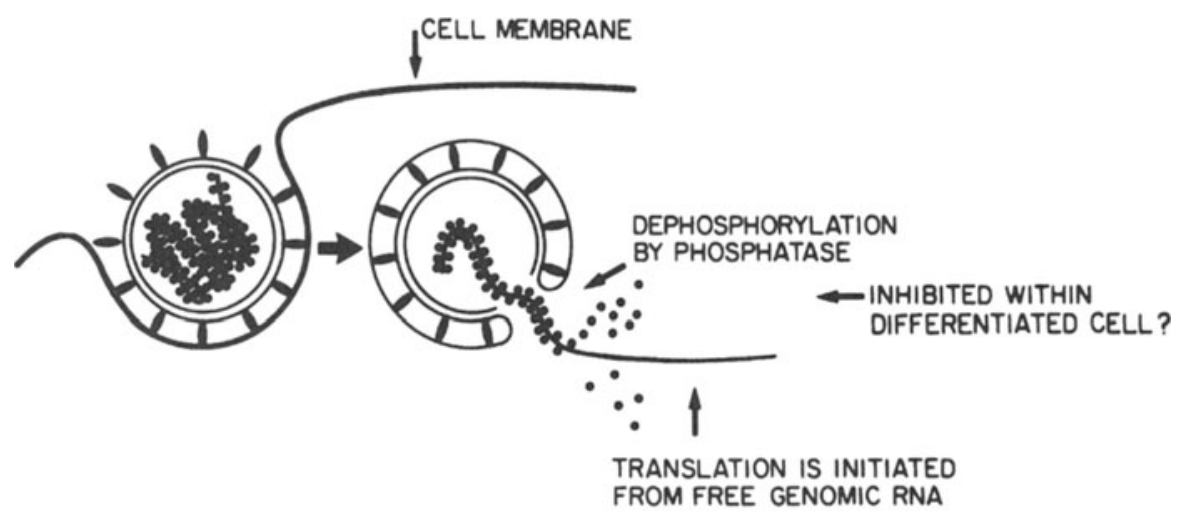

\section{EARLY CELL-VIRUS INTERACTIONS}

FIGURE 2. Diagrammatic representation of the early events connected with MCV uncoating. Dephosphorylation of NC protein is proposed as a necessary event for initiation of processing of NC to facilitate conformational relaxation of the genome and/or release of NC from the genome to allow the expression of subsequent virus-specified functions.

alitis is achieved by passive immunization with MAb against viral envelope glycoproteins S, M, and HE. Such immunization, however, fails to arrest the delayed, demyelinating form of disease and may in fact promote it (Fleming et al., 1989). Our own studies with rat tetencephalic cultures suggest that the subacute disease with demyelination may occur only after survival of the acute, encephalitic phase of disease (Pasick and Dales, 1991). An antibody-mediated shift in tropism is indicated by the interference with neuronal, but not OL infections, when MAb against S or HE is employed (Buchmeier et al., 1984; Yokomori et al., 1992). This implies that complement-mediated cytolysis or antibody-dependent, cell-mediated cytotoxicity (ADCT) may eliminate infected targets following the mobilization and infiltration of mononuclear cells. In addition, an increase of $\mathrm{B}$ and plasma cells as well as $\mathrm{IgG}^{+}$complement deposits within demyelinating lesions of WL rats (Zimprich et al., 1991) is consistent with the possible role of ADCT.

During acute phases of murine CNS infection by JHMV, the T-cell response may be crucial in mediating clearance of virus and arrest of the disease process. Upon adoptive transfer of $\mathrm{CD}^{+}{ }^{+}$, Lyt2-cloned $\mathrm{T}$ cells specific for JHMV, C57BL/6 mice are protected from developing lethal encephalitis by an major histocompatability complex II (MHC-II)-restricted delayed type hypersensitivity (DTH) response (Stohlman et al., 1986, 1988), without a reduction in virus titer in the CNS. Such protected mice subsequently manifest OL demyelinating disease. The CNS concentrations of anti-JHMV antibodies are not altered in the above T-cell recipients or in WF rats with demyelinating lesions (Sorensen et al., 1984b). It can be concluded from these data that the local synthesis of antiviral antibodies within the CNS does not prevent demyelination. The adoptive transfer of T-cell clones specific for JHMV can also protect 
against encephalitis by reducing virus replication in neurons (Stohlman et al., 1986). Furthermore, some data suggest that the clearance of JHMV from the CNS of mice appears to involve both $\mathrm{CD}^{+}{ }^{+}$and $\mathrm{CD} 8{ }^{+} \mathrm{T}$ cells (Sussmann et al., 1989; Williamson and Stohlman, 1990; Yamaguchi et al., 1991). These results are in line with the evocation of a CTL response against the carboxy-terminal end of $\mathrm{N}$ (Stohlman et al., 1992). Another study, however, failed to demonstrate cytotoxic lymphocytes (CTLs) against viral components in C57BL/6 mice, although other T-helper cell responses were detected (Mobley et al., 1992). Complementary studies employing athymic, nude mice and rats or animals treated with immunosuppressing agents confirmed the involvement of cellular immunity in the disease process. They showed that, relative to control animals, gray matter and neuronal involvement is enhanced during T-cell deficiency, resulting in acute encephalitic rather than demyelinative, white matter disease (Sorensen et al., 1982, 1987b; Zimmer and Dales, 1989; Pasick et al., 1992).

Postweanling rats challenged with JHMV do not exhibit any disease symptoms, but on histological examination show signs of limited CNS histopathology and some virus expression. The age-limited resistance does not apply to athymic nude $(\mathrm{nu} / \mathrm{nu})$ rats or animals treated with the immunosuppressants cyclophophosphamide and cyclosporin A (Sorensen et al., 1987b; Zimmer and Dales, 1989). Rats challenged with virus even beyond 70 days of age develop a late-onset encephalitic form of disease that is rapidly fatal. Histopathology reveals wide dissemination of infection in neuron-rich gray matter but a limited involvement of white matter, where small foci of demyelination develop during the late-onset disease. In adult mice of strains that are normally resistant to A59, MHV3, and JHMV MCV infections, when initiated by the IN and IP routes, immunosuppression promotes a similar, late-onset encephalitis arising from extensive neuronal damage (Sorensen et al., 1982, 1984a,b). It appears that CNS neurons in older rats and mice are fully susceptible to infection but replication and dissemination of MCV progeny is suppressed when cellular immune responses are activated. Presumably, the paucity of susceptible OL targets for MCV infection within the CNS of mature animals results in a limitation of pathogenesis, manifested as very small WM demyelinating lesions (Sorensen et al., 1987b; Zimmer and Dales, 1989).

Consistent with the in vivo situation, the susceptibility of neurons can also be demonstrated with cortical explants from rat embryos that are maintained in long-term culture. Unlike explanted OL, which are intrinsically programmed to differentiate within 3 weeks after birth or at an accelerated rate by treatment with dbcAMP (Raff, 1989; Beushausen and Dales, 1985), isolated neurons remain susceptible to persistent JHMV infection for long periods of time and can produce large quantities of virus after pretreatment with dbcAMP (Pasick and Dales, 1991). The late-onset, fulminant infection of neurons in immunosuppressed rats might commence from a reservoir of virus at a foci of latency, perhaps in neurons of the cerebellum and hippocampus (Sorensen and Dales, 1985).

Unlike cellular immunity, the humoral immune responses that occur within the CNS compartment following infection of WF and WL rats fail to suppress virus replication or interrupt the development of disease (Sorensen et al., 1984b). In Brown Norway rats, a vigorous humoral immunity within the 
CNS develops after JHMV infection, which could explain why there is a suppression of disease and virus replication in this model (Dörries et al., 1987).

The infection of macrophages and lymphotropism of MHV3 during infection of partially susceptible $(\mathrm{C} 57 \mathrm{BL} / 6 \times \mathrm{A} / \mathrm{J}) \mathrm{F}_{1}$ mice initially causes a low-grade infection of the liver, then of the brain. Upon spreading to the CNS, the infection produces paralytic symptoms, sometimes lasting for periods as long as $1 \mathrm{yr}$. Lymphotropism is associated with a progressive decline of immunoglobulin production during the initial 3 months, then a return to normal levels (Leray et al., 1982). After introduction of JHMV by IN inoculation, adult BALB/c mice become protected against challenge for 12 months. This is due to antibodies raised against the initial inoculation (Barthold and Smith, 1989). The virus may incite an autoimmune disease process in WL rats and SJL/J mice, which follows myelin destruction, as described in Section IV. Autoimmunity was postulated to involve expression of the MHC-I associated (Ia) determinant on AS when these cells become differentiated into antigen-presenting cells due to the presence of JHMV (Massa and ter Meulen, 1987; Calder et al., 1988). This phenomenon does not appear to pertain in mice, in which only class I H-2 antigen presentation is observed in AS and OL (Suzumura et al., 1986, 1988). The presentation of class I H-2 required continuous presence or formation of viable A-59 virus and is mediated by factors produced in glial cells, probably AS (Lavi et al., 1989).

\section{GENETIC VARIABILITY OF VIRUS AND HOST AS DETERMINANTS OF PATHOGENESIS AND DISEASE}

Differences in the cytopathology and disease process in animals are greatly affected by the genotypes of both the virus and the host. During interactions with cell targets, the S peplomer is most probably the major determinant of tropism, virulence or attenuation, and cytopathology. The host controls the disease process and susceptibility or resistance to infection at the cellular and organismic level, including responses by the immune system.

\section{A. Relationship of the CV Replication Strategy to Genetic Variability}

An understanding of the $\mathrm{CV}$ replication strategy can explain why these agents have the capacity to evolve rapidly into diverse genetic variants. Thus, transcription by means of discontinuous, leader-primed synthesis (Lai, 1986), as well as the occurence of subgenomic replicative intermediates (Sethna et al., 1989; Sawicki and Sawicki, 1990), provide possible mechanisms for highly efficient recombination among the nonsegmented CV genomes (Lai et al., 1985). Based on the currently available CV genomic and mRNA sequences, it is possible to explain the genesis of diversity observed among MCV progeny following passage through cells in culture or during CNS infection of animals. Also, in the case of $\mathrm{HCV}$, circulating among human populations, genetic variability could arise by repeated OC43 and 229E reinfections of the upper respiratory tract (MacNaughton, 1982; Reed, 1984). 
The occasional association of OC43 infections of humans with neurological symptoms (Hellevi and Hovi, 1980) and the induction of a demyelinating disease process by MCV in rodents and monkeys have a bearing on the search for an etiologic infectious agent in multiple sclerosis (MS). However, the claim that two CV isolates, designated SK and SD, had originated from the tissue of MS patients (Mendelman et al., 1983) remains questionable. Sensitive antigen detection (Hasony and MacNaughton, 1982) and nucleic acid probes (Weiss, 1983; Weiss and Leibowitz, 1983) that are able to discriminate between HCV and MCV have grouped SK and SD viruses with MCV (Weiss, 1983).

\section{B. Role of $S$ in Pathogenesis and Disease}

The S peplomer, which is involved in attachment, penetration, syncytiogenesis, and other aspects of cytopathology, appears to be one of the most variable component of coronavirions. In addition to molecular diversity in S from the various $\mathrm{CV}$ strains infecting mammals, variability in the MCV S protein arises during passage through rodents, generating antigenic and pathogenicity variants, as summarized in Table II. An important location for molecular modulation could be a hypervariable RNA sequence indentified in the S gene (Parker et al., 1989). During replication, this region may either be a preferred crossing over site or a site of strong selection, thereby giving rise to recombinants of $S$ in which modifications, including deletions, are introduced frequently.

The unquestionable role of $S$ in cytopathogenicity and neuroattenuation was demonstrated when $S$ was expressed by means of a vaccinia virus recombinant vector. This experiment of Daya et al. (1989) demonstrated unequivocally that $S$, by itself, can induce the same cytopathology as the MCV from which it was derived. Also, it has been possible to identify separate regions on $\mathrm{S}$ associated with pathogenicity and other functions (Table II). These various biological activities of $S$ were mapped using panels of MAbs able to affect individual functions of this G-P. Thus, three topologically distinct antigenic sites, eliciting protective cellular or humoral responses in mice, were identified on the $S$ protein of JHMV by Talbot et al. (1984). The survival of mice was associated with decreased virus production and confinement of the infection to neurons, sparing the glia (Buchmeier et al., 1984).

Another comparative study on the MCV strains MHV-1, -3, -5, JHM, and A59 demonstrated the presence of five antigenic sites, A through E, among which $B$ is involved with neurotropism and $C$ with virulence (Talbot and Buchmeier, 1985). Such analyses also uncovered polymorphism in the S protein of JHMV variants isolated after escaping neutralization by MAb (Dalziel et al., 1986; Buchmeier et al., 1988). Some isolates obtained in this manner were attenuated and others more virulent when compared with the parental JHMV. Attenuation was manifested through a requirement for larger inocula to initiate CNS disease and a change in preferential tropism from neurons to OL. Thus, a paralytic, demyelinating disease rather than an acute encephalitis was elicited (Buchmeier et al., 1988). Controlled dual infection with JHMV and A59 has also 
generated recombinants in the $S$ gene. Epitope mapping carried out with MAb demonstrated that the critical determinant(s) for neuropathogenicity occur at the C terminal one third of the S protein (Makino et al., 1987; Gallagher et al., 1990). In some variants, attenuation is linked with a ts phenotype of the virus, as in the case of one A59 isolate that replicated at a normal rate in Sac(-) cells but behaved as $t s$ in glial cultures and was mildly neuropathogenic in mice (van Berlo et al., 1986; Koolen et al., 1983). From this and other findings, it becomes evident that a temperature restriction regulating $\mathrm{CV}$ infection can be exerted by the neural cell host and is not due to thermosensitivity of the virus, as discussed in Section II.G (Lucas et al., 1978; van Berlo et al., 1986; Koolen et al., 1983).

It is possible that some phenotypic variations of $S$ are due to point mutations alone, but it is known that during passage through neural cells in explants or within the CNS, the $S$ protein of the emerging stable variants undergoes considerable changes, as described in Table II. One JHMV isolate, passaged in C1300 neuroblastoma, possessed a deletion in S and coincidentally became nonsyncytiogenic (Lavi et al., 1990). In another JHMV isolate from the CNS that could replicate more efficiently in AS, the mRNA encoding $S$ was larger (Taguchi et al., 1986). In another study of six JHMV isolates from mouse CNS, four were shown to possess larger and two smaller than normal length $S$ genes. In the smaller S variants, sequence deletions were linked with an attenuated phenotype producing a subacute demyelinating disease in mice (Taguchi and Fleming, 1989).

Similar modulations in S of JHMV were generated by passage through the CNS of rats. One report described a stable change to a larger S polypeptide (Taguchi et al., 1985). As described in Table II, genetically stable JHMV variants have been isolated and different phenotypes for the induction of neurological disease in the white and gray matter of the CNS can be recognized (Baybutt $e t$ al., 1984; Morris et al., 1989). One such attenuated isolate from spinal cord (SC), termed AT1lf, has a deletion in S, is highly fusogenic for cells in culture, and rather specific for inducing SC demyelination (Morris et al., 1989). AT1lf overcomes the resistance of explanted glial cells in adult SJL/J mice, apparently, unlike infection with parental JHMV, because dissemination of the AT1lf progeny is not as restricted and high titers are produced (Pasick et al., 1992). Thus, an alteration in $S$ has made this isolate more, not less, virulent for mouse neural cells. A double mutant attenuated in both encephalitic and demyelinating potential contained a point mutation within S2 plus a deletion in the hypervariable region of S1 (Fleming et al., 1986, 1987). This finding led to the conclusion that the role of $S$ in demyelination may involve multiple determinants on this molecule (Wang et al., 1982). Evidently, care must be taken in defining attenuation and virulence as it pertains to diseases produced by these variants.

\section{Influence of the Genetic Constitution of the Host}

There is abundant documentation that the resistance or susceptibility to $\mathrm{MCV}$-induced disease process is controlled by the genetic determinants of the host. With mice, the determinants have been recognized at the cellular level. 


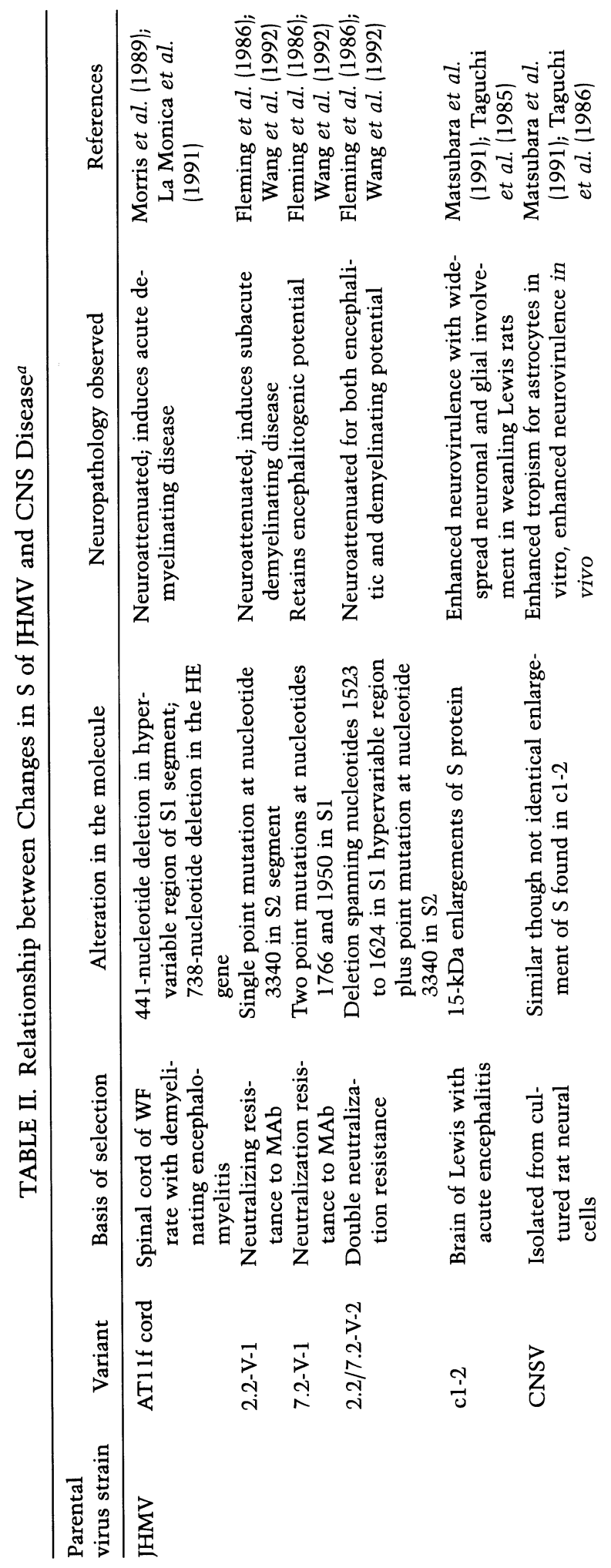




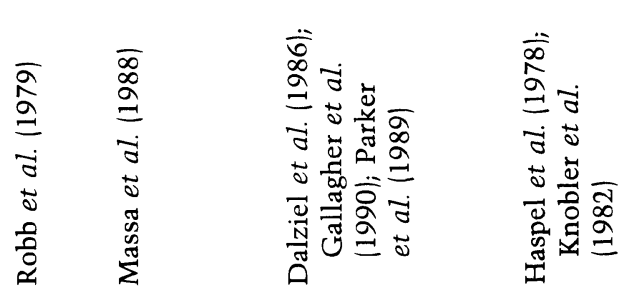

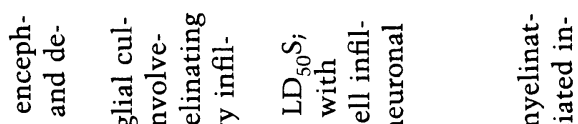

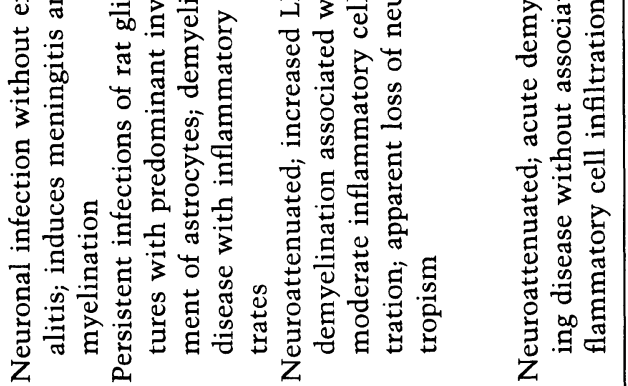

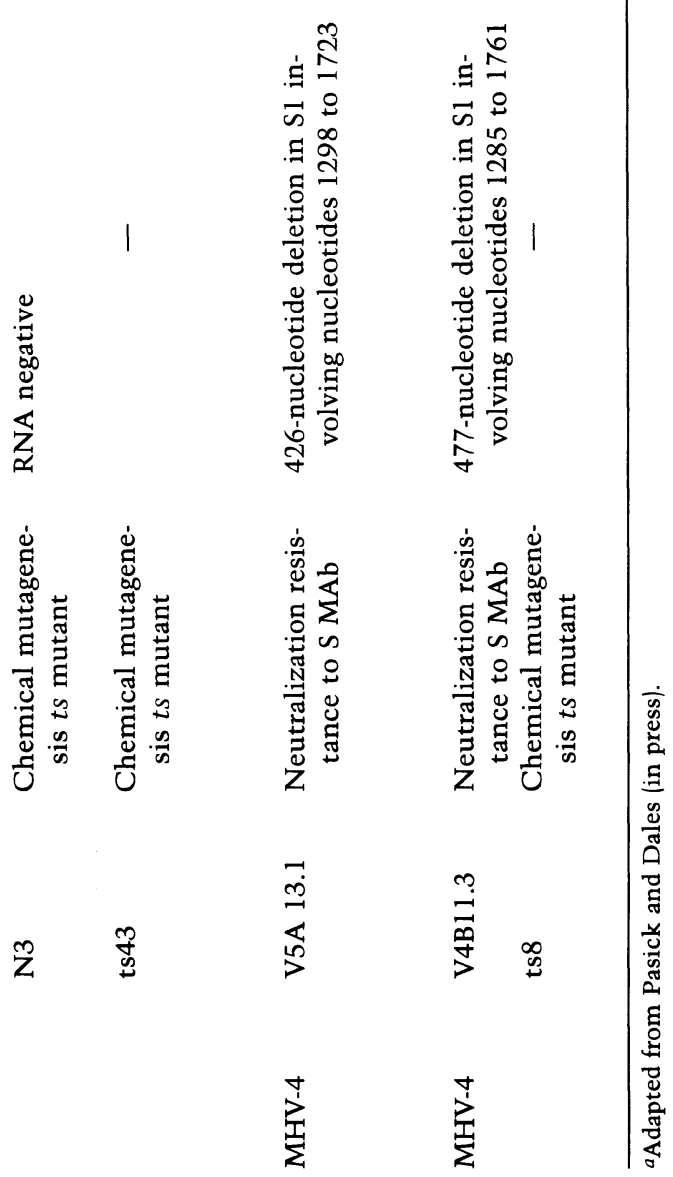


Notably, SJL/J mice resist infection by JHMV but not by the related MHV3. This distinction between virus strains becomes clear when different primary cell types are challenged, including neurons, macrophages (Knobler et al., 1981), AS, and OL (Wilson and Dales, 1988). In contrast to SJL/J mice, A/J adults and their peritoneal exudate macrophages are resistant to MHV3. By challenging IN the hybrid mice crosses SJL/J $\times$ CD.1 and $\mathrm{A} / \mathrm{J} \times \mathrm{DBA}$ and explanted cells from these crosses, it can be demonstrated (as shown in Table III) that resistance is manifested as a recessive trait (reviewed in Wilson and Dales, 1988). This result is consistent with the idea that a specific, cellular protease is required to activate $S$ by cleavage to $S_{1}$ and $S_{2}$, and thus promote the spread of infection. However, the disease pattern produced with the virus when inoculated into $F_{1}$ mice is unlike that expected from fully susceptible mouse strains. For example, IP challenge of the $F_{1} A / J \times D B A$ cross with $M H V 3$, rather than inducing a fulminant visceral and liver disease, instead elicits late-onset neurological symptoms with paralysis (Sorensen et al., 1982; Le Prévost et al., 1975). Evidently some additional factor $(\mathbf{s})$ is controlling virus expression and influencing the in vivo disease process.

It has been suggested that any variable that influences survival of the animal host, following virally induced encephalitis, results in the subsequent manifestation of a demyelinating form of disease (Fleming et al., 1989). Our own studies indicate that subacute demyelination may occur after the host has undergone a transitory and limiting form of encephalitis (Pasick and Dales, 1991).

Genetic variability of the cellular immune response could be one of such factor determining the outcome of the disease process. Peritoneal macrophages

TABLE III. Comparison of Replication in Glial Cultures from Purebred and Hybrid Mice ${ }^{a, b}$

\begin{tabular}{|c|c|c|c|c|}
\hline \multirow{2}{*}{$\begin{array}{l}\text { Mouse strain } \\
\text { from which } \\
\text { culture } \\
\text { originated }\end{array}$} & \multirow{2}{*}{$\begin{array}{c}\text { Time after } \\
\text { inoculation } \\
(\mathrm{hr})\end{array}$} & \multicolumn{3}{|c|}{ Titer $\left(10^{2} \mathrm{PFU} / \mathrm{ml}\right)^{c}$} \\
\hline & & $\mathrm{JHMV}^{c}$ & $\mathrm{MHV}^{d}$ & $\mathrm{~A} 59^{d}$ \\
\hline \multirow[t]{4}{*}{ SJL } & 12 & $0.17 \pm 0.29(3)$ & $590 \pm 114(3)$ & $6 \pm 2(6)$ \\
\hline & 24 & $23 \pm 12(14)$ & $435 \pm 292(14)$ & $13 \pm 0.5(6)$ \\
\hline & 48 & $48 \pm 20(14)$ & $886 \pm 62 / 10$ & $2 \pm 0.6(3)$ \\
\hline & 72 & $22 \pm 9(12)^{\prime}$ & $475 \pm 119(6)$ & $\mathrm{ND}^{e}$ \\
\hline \multirow[t]{3}{*}{ CD.1 } & 12 & $350 \pm 216(5)$ & $77 \pm 12(4)$ & ND \\
\hline & 24 & $3,260 \pm 2,110(13)$ & $778 \pm 30(11)$ & $21,300 \pm 19,600(3)$ \\
\hline & 48 & $9,400 \pm 500(9)$ & $3,340 \pm 2,300(7)$ & $95,800 \pm 2,700(3)$ \\
\hline \multirow{3}{*}{$(\mathrm{CD} .1 \times \mathrm{SJL}) \mathrm{F}_{1}$} & 24 & $961 \pm 34(5)$ & $1,120 \pm 730(5)$ & ND \\
\hline & 48 & $6,260 \pm 4,320(5)$ & $2,400 \pm 2,000(5)$ & ND \\
\hline & 72 & $943 \pm 480(5)^{f}$ & $213 \pm 52(5)^{f}$ & ND \\
\hline
\end{tabular}

${ }^{a}$ From Wilson and Dales (1988).

$b$ Primarily oligodendrocytes and astrocytes (35).

$c$ The values are means with standard deviations. The number of cultures tested is shown in parentheses.

${ }^{d}$ MOI, 1 PFU per cell.

eND, not determined.

fDecrease in titers was attributed to rapid cell killing. 
from a substrain of $\mathrm{C}_{3} \mathrm{H}$ mice, normally resistant to $\mathrm{MCV}$, became susceptible if the host had been pretreated with hydrocortisone, implying that a lymphokineinduced resistance was involved (Taylor et al., 1981). Infection of susceptible C57BL/6 mice with MHV3 may abrogate or depress cellular immunity directly because the virus is lymphotropic, hence immunosuppressive, and causes the spleen and thymus to atrophy (Lamontagne et al., 1989). The role of macrophages in the MHV3 disease process can be demonstrated in the adoptive transfer of resistance by means of bone marrow cells from resistant into susceptible X-irradiated mouse recipients (Lamontagne et al., 1989; Dupuy et al., 1984).

Among rats, strain WF has a more prolonged age-related susceptibility to inoculation with JHMV than WL and other strains (Sorensen et al., 1982). The tropism of this virus for immature OL in vitro (Beushausen and Dales, 1985; Wilson et al., 1986; Beushausen et al., 1987) and the documented, extended duration of susceptibility to JHMV in postnatal, preweanling WF rats may be connected. Since the maturation of the CNS in this strain is slower, presumably due to genetic deficiency of circulating growth hormone (reviewed in Sorensen et al., 1980), a greater number of infectable OL progenitors might be present for a longer duration in WF versus WL rats. As is the case with the mouse, rats also manifest genetic variation of immune responses, which are superimposable on virus-target cell interactions. An autoimmune type of disease, similar to experimental allergic encephalomyelitis (EAE), was recognized following JHMV infection of WL rats (Watanabe et al., 1983; Wege et al., 1984). This strain is readily inducible for EAE by inoculation with myelin components. However, despite similarities in appearances of demyelinating lesions evident in WL and WF rats, EAE cannot be induced with myelin antigens in WF rats (Zimmer and Dales, 1989). These combined data indicate that JHMV infection of WL rats may elicit a primary demyelination due to OL infection, as well as an EAE-like disease, provoked by circulating myelin antigens released by cytolysis of infected OL. This duality of disease processes may occur in WL rats, perhaps because they are endowed with a high frequency of T-cell responders to myelin basic protein.

In rats, naturally or deliberately made deficient in cellular immunity, susceptibility to JHMV-related CNS disease becomes extended indefinitely beyond weaning. Athymic nu/nu rats undergo a late-onset acute encephalitis with only a limited white matter involvement, evident by the presence of small lesions (Sorensen et al., 1987b). The disease process is primarily connected with fulminant gray matter neuronal infections, which cannot be kept in check due to a genetic deficiency of cellular immunity. Humoral immune responses, although they do occur locally within the CNS of JHMV-infected WL and WF rats, appear not to influence the demyelinative disease process (Sorensen $e t$ al., 1984b; Dörries et al., 1986). On the other hand, a vigorous humoral immunity detected in the CNS of BN rats could explain why the disease is suppressed in this strain (Dörries et al., 1987).

From the above considerations, it is evident that genetic variability of the virus and the host can result in differing diseases in animals and varying cytopathic responses when infections are carried out in vitro. Within the animal there are additional important factors, most notably the immune system, 
that also determine the nature of pathogenesis and type of disease that develops.

\section{SUMMARY}

Based on the information reviewed in this chapter, it becomes clear that both the virus and host are involved in determining the outcome of CNS infections by MCV. The current information is consistent with the idea that virus tropism for specific cell types within the CNS is profoundly influenced by: (1) the state of maturation of the CNS, i.e, by cell lineages and parameters controlling differentiation; (2) immune responses; and (3) possibly, evolution of genetic variants of the virus. Thus, pathogenesis and neurological disease in this complex rodent model of virus infection become a manifestation of an interplay between the above three, equally important, parameters.

\section{REFERENCES}

Aloisi, F., Agresti, C., D’Urso, D., and Levi, G., 1988, Differentiation of bipotential glial precursors into oligodendrocytes is promoted by interaction with type 1 astrocytes in cerebellar cultures, Proc. Natl. Acad. Sci. USA 85:6167.

Amako, K., and Dales, S., 1967, Cytopathology of mengovirus infection. II. Proliferation of membranous cisternae, Virology 32:201.

Anderson, R., and Wong, F., 1993, Membrane and phospholipid binding by murine coronaviral nucleocapsid N protein, Virology 194:224.

Appleyard, G., and Tisdale, M., 1985, Inhibition of the growth of human coronavirus 229E by leupeptin, J. Gen. Virol. 66:363.

Armstrong, J., Smeekens, S., and Rottier, P., 1983, Sequence of the nucleocapsid gene from murine coronavirus MHV-A59. Nucleic Acids Res. 11:883.

Arnheiter, H., Baechi, T., and Haller, O., 1982, Adult mouse hepatocytes in primary monolayer culture express genetic resistance to mouse hepatitis virus type 3, J. Immunol. 129:1275.

Asano, K., and Asano, A., 1988, Binding of cholesterol and inhibitory peptide derivatives with the fusogenic hydrophopic sequence of F-glycoprotein of HVJ (Sendai virus): Possible implication in the fusion reaction, Biochemistry 27:1321.

Bailey, O. T., Pappenheimer, A. M., Cheever, F. S., and Daniels, J. B., 1949, A murine virus (JHM) causing disseminated encephalomyelitis with extensive destruction of myelin. II. Pathology, $J$. Exp. Med. 90:195.

Bang, F. B., and Warwick, A., 1960, Mouse macrophages as host cells for the mouse hepatitis virus and the genetic basis for their susceptibility, Proc. Nat1. Acad. Sci. USA 46:1065.

Barthold, S. W., and Smith, A. L., 1984, Mouse hepatitis virus strain-related patterns of tissue tropism in suckling mice, Arch. Virol. 81:103.

Barthold, S. W., and Smith, A. L., 1989, Duration of challenge immunity to coronavirus JHM in mice, Arch. Virol. 107:171.

Barthold, S. W., Beck, F. S., and Smith, A. L., 1986, Mouse hepatitis virus nosoencephalopathy is dependent upon virus strain and host genotype, Arch. Virol. 91:247.

Baybutt, H. N., Wege, H., Carter, M. J., and Ter Meulen, V., 1984, Adaptation of coronavirus JHM to persistent infection of murine sac(-) cells, J. Gen. Virol. 65:915.

Beushausen, S., and Dales, S., 1985, In vivo and in vitro models of demyelinating disease. IX. Tropism and differentiation regulate the infectious process of coronaviruses in primary explants of the rat CNS, Virology 141:89.

Beushausen, S., Narindrasorasak, K., Sanwal, B. D., and Dales, S., 1987, In vivo and in vitro models 
of demyelinating disease: Activation of the adenylate cyclase system influences JHM virus expression in explanted rat oligodendrocytes, $J$. Virol. 48:3795.

Bögler, O., Wren, D., Barnett, S. C., Land, H., and Noble, M., 1990, Cooperation between two growth factors promotes extented self-renewal and inhibits differentiation of ologodendrocyte-type 2 astrocyte (O2-A) progenitor cells, Proc. Nat1. Acad. Sci. USA 87:6368.

Bouloy, M., Plotch, S. J., and Krug, R. M., 1980, Both in the 7-methyl and the 2'-O-methyl groups in the cap of mRNA strongly influence its ability to act as primer for influenza virus RNA transcription, Proc. Natl. Acad. Sci. USA 77:3952.

Boyle, J. F., Weismiller, D. G., and Holmes, K. C., 1987, Genetic resistance to mouse hepatitis virus correlates with absence of virus-binding activity on target tissue, I. Virol. 61:185.

Bruce, C. B., Chapman, J., Suckling, A. J., and Rumsby, M. G., 1984, Infection of rat brain primary cell cultures with an avirulent A7 strain of Semliki forest virus, J. Neuro. Sci. 66:77.

Buchmeier, M. J., Lewicki, H. A., Talbot, P. J., and Knobler, R. L., 1984, Murine hepatitis virus-4 (strain JHM)-induced neurologic disease is modulated in vivo by monoclonal antibody, Virology 132:261.

Buchmeier, M. J., Dalziel, R. G., and Koolen, M. J. M., 1988, Coronavirus-induced CNS disease: A model for virus-induced demyelination, $J$. Neuroimmun. 20:111.

Burks, J. S., Devald, B. L., Jankovsky, L. D., and Gerdes, J. C., 1980, Two coronaviruses isolated from central nervous system tissue of two multiple sclerosis patients, Science 209:933.

Calder, V. L., Wolswijk, G., and Noble, M., 1988, The differentiation of O-2A progenitor cells into oligodendrocytes is associated with loss of inducibility of la antigens, Eur. J. Immunol. 18:1195.

Carrasco, L., and Smith, A. E., 1976, Sodium ions and the shut off of host cell protein synthesis by picornaviruses, Nature 264:807.

Cavanagh, D., Brian, D. A., Enjuanes, L., Holmes, K., Lai, M., Laude, S., Siddell, S., Spaan, W., Taguchi, F., and Talbot, P., 1990, Recommendations of the coronavirus study group for the nomenclature of the structural proteins, mRNAs, and genes of coronaviruses, Virology 176:306.

Cervin, M., and Anderson, R., 1991, Modulation of coronavirus-mediated cell fusion by homeostatic control of cholesterol and fatty acid metabolism, J. Med. Virol. 35:142.

Cheever, F. S., Daniels, J. B., Pappenheimer, A. M., and Bailey, O. T., 1949, A murine virus causing disseminated encephalomyelitis with extensive destruction of myelin I. Isolation and biological properties of the virus, J. Exp. Med. 90:181.

Cheley, S., and Anderson, R., 1981, Cellular synthesis and modification of murine hepatitis virus polypeptides, J. Gen. Virol. 54:301.

Cheley, S., Morris, V. L., Cuppels, M. J., and Anderson, R., 1981, RNA and polypeptide homology among murine coronaviruses, Virology 115:310.

Collins, A. R., and Sorensen, O., 1986, Regulation of viral persistence in human glioblastoma and rhabdomyosarcoma cells infected with coronavirus OC43, Microb. Pathol. 1:573.

Collins, A. R., Knobler, R. L., Powell, H., and Buchmeier, M. J., 1982, Monoclonal antibodies to murine hepatitis virus-4 (strain JHM) define the viral glycoprotein responsible for attachment and cell-cell fusion, Virology 119:358.

Collins, A. R., Runison, A. L., and Knobler, R. L., 1983, Mouse hepatitis virus type 4 infection of primary glial cultures from genetically susceptible and resistant mice, Infect. Immun. 40:1192.

Coulter-Mackie, M. B., Flintoff, W. F., and Dales, S., 1984, In vivo and in vitro models of demyelinating disease. X. A Schwannoma-L-2 somatic cell hybrid persistently yielding high titres of mouse hepatitis virus strain JHM, Virus Res. 1:477.

Coulter-Mackie, M., Adler, R., Wilson, G., and Dales, S., 1985, In vivo and in vitro models of demyelinating diseases. XII. Persistence and expression of corona JHM virus functions in RN2-2 schwannoma cells during latency, Virus Res. 3:245.

Dalziel, R. G., Lampert, P. W., Talbot, P. J., and Buchmeier, M. J., 1986, Site-specific alteration of murine hepatitis virus type 4 peplomer glycoprotein E2 results in reduced neurovirulence, $I$. Virol. 59:463.

David-Ferreira, J. F., and Manaker, R. A., 1965, An electron microscope study of the development of a mouse hepatitis virus in tissue culture cells, I. Cell. Biol. 24:57.

Davies, H. A., Dourmashkin, R. R., and MacNaughton, M. R., 1981, Ribonucleoprotein of avian infectious bronchitis virus, J. Gen. Virol. 53:67. 
Daya, M., Cervin, M., and Anderson, R., 1988, Cholesterol enhances mouse hepatitis virusmediated cell fusion, Virology 163:276.

Daya, M., Wong, F., Cervin, M., Evans, G., Vennema, H., Spaan, W., and Anderson, R., 1989, Mutation of host cell determinants which discriminate between lytic and persistent mouse hepatitis virus infection results in a fusion-resistant phenotype, I. Gen. Virol. 70:3335.

Dörries, R., Watanabe, R., Wege, H., and Ter Meulen, V., 1986, Murine coronavirus-induced encephalomyelitides in rats: Analysis of immunoglobulins and virus-specific antibodies in serum and cerebrospinal fluid, J. Neuroimmun. 12:131.

Dörries, R., Watanabe, R., Wege, H., and Ter Meulen, V., 1987, Analysis of the intrathecal humoral response in Brown Norway (BN) rats, infected with murine coronavirus JHM, I. Neuroimmun. 14:305.

Doughri, A. M., Storz, J., Hajer, I., and Fernando, H. S., 1976, Morphology and morphogenesis of a coronavirus infecting intestinal epithelial cells of newborn calves, Exp. Mol. Pathol. 25:355.

Dubois-Dalq, M. E., Doller, E. W., Haspel, M. V., and Holmes, K. V., 1982, Cell tropism and expression of mouse hepatitis virus (MHV) in mouse spinal cord cultures, Virology 119:317.

Dupuy, J. M., Dupuy, C., and Decarie, D., 1984, Genetically determined resistance to mouse hepatitis virus 3 is expressed in hematopoeietic donor cells in radiation chimeras, J. Immunol. 133:1609.

Fabre, M., Langley, O. K., Bologia, L., Delaundy, J-P., Lowenthal, A., Ferret-Jena, V., Vincendon, G., and Sarliève, L., 1985, Cellular development and myelin production in primary cultures of embryonic mouse brain, Dev. Neurosci. 7:323.

Fernandez-Munoz, R., and Darnell, J.E., 1976, Structural differences between the 5 '-termini of viral and cellular mRNA in poliovirus-infected cells, $J$. Virol. 18:719.

Fleming, J. O., Trousdale, M. D., El-Zaatari, F. A. K., Stohlman, S. A., and Weiner, L. P., 1986, Pathogenicity of antigenic variants of murine coronavirus JHM selected with monoclonal antibodies, $J$. Virol. 58:869.

Fleming, J. O., Trousdale, M. D., Bradbury, J., Stohlman, S. A., and Weiner, L. P., 1987, Experimental demyelination induced by coronavirus JHM (MHV-4): Molecular identification of a viral determinant of paralytic disease, Microb. Pathol. 3:9.

Fleming, J. O., Shubin, R. A., Sussman, M. A., Casteel, N., and Stohlman, S. A., 1989, Monoclonal antibodies to the matrix (E1) glycoprotein of mouse hepatitis virus protect mice from encephalitis, Virology 168:162.

Flintoff, W. F., and van Dinter, S., 1989, Several rat cell lines share a common defect in their inability to internalize murine coronaviruses efficiently, $J$. Gen. Virol. 70:1713.

Frana, M. F., Behnke, J. N., Struman, L. S., and Holmes, K. V., 1985, Proteolytic cleavage of the E2 glycoprotein of murine coronavirus: Host-dependent differences in the proteolytic cleavage and cell fusion, $J$. Virol. 56:912.

Gallagher, T. M., Parker, S. E., and Buchmeier, M. J., 1990, Neutralization-resistant variants of a neurotropic coronavirus are generated by deletions with the amino-terminal half of the spike glycoprotein, $J$. Virol. 64:731.

Gallwitz, D., Traub, U., and Traub, P., 1977, Fate of histone messenger RNA in mengovirus-infected Ehrlich ascites tumor cells, Eur. J. Biochem. 81:387.

Gard, A. L., and Pfeiffer, S. E., 1989, Oligodendrocyte progenitors isolated directly from developing telencephalon at a specific phenotypic stage: Myelinogenic potential in a defined environment, Development 106:119.

Gombold, J. L., Hingley, S. T., and Weiss, S. R., 1993, Fusion-defective mutants of mouse hepatitis virus A59 contain a mutation in the spike protein cleavage signal, J. Virol. 67:4504.

Greene, L. E., and Eisenberg, E., 1988, Effect of phosphatase on the ability of the uncoating ATPase to dissociate clathrin from coated vesicles, J. Cell. Biol. 107A:773.

Hasony, H. J., and MacNaughton, M. R., 1982, Serological relationships of the subcomponents of human coronavirus strain HCV 229E and mouse hepatitis virus 3, J. Gen. Virol. 58:449.

Haspel, M. V., Lampert, P. W., and Oldstone, M. B. A., 1978, Temperature-sensitive mutants of mouse hepatitis virus produce a high incidence of demyelination, Proc. Natl. Acad. Sci. USA, 75:4033.

Hellevi, R., and Hovi, T., 1980, Coronavirus infections of man associated with diseases other than the common cold, J. Med. Virol. 6:259. 
Hilton, A., Mizzen, L., MacIntyre, G., Cheley, S., and Anderson, R., 1986, Translational control in murine hepatitis virus infection, J. Gen. Virol. 67:923.

Hirano, N., Goto, N., Ogawa, T., Ono, K., Murakani, T., and Fujiwara, K., 1980, Hydrocephalus in suckling rats infected intracerebrally with mouse hepatitis virus MHV-A59, Microb. Immunol. 24:825.

Kaufman, Y., Goldstein, E., and Penman, S., 1976, Poliovirus-induced inhibition of polypeptide initiation in vitro on native polysomes, Proc. Nat1. Acad. Sci. USA 73:1834.

Kersting, G., and Pette, E., 1956, Pathohistologie und Pathogenese der experimentellen JHMVirusencephalomyelitis des Affen, Dtsch. Nervenheilkund. 174:283.

Kienzle, T. E., Abraham, S., Hogue, B. G., and Brian, D., 1990, Structure and orientation of expressed bovine coronavirus hemagglutinin-esterase protein, $J$. Virol. 64:1834.

Klumperman, J., Krijnse-Locke, J., Meijer, A., Horzinek, M. C., Geuze, H., and Rottier, P. J. M., 1994, Coronavirus $M$ proteins accumulate in the Golgi complex beyond the site of virion budding, $J$. Virol. 68:6523.

Knobler, R. L., Haspel, M. V., and Oldstone, M. B. A., 1981, Mouse hepatitis virus type 4 (JHM strain)-induced fatal central nervous system disease, J. Exp. Med. 153:832.

Knobler, R. L., Lampert, P. W., and Oldstone, M. B. A., 1982, Virus persistence and recurring demyelination produced by a temperature-sensitive mutant of MHV, Nature 298:279.

Knobler, R. L., Tunison, L. A., and Oldstone, M. B. A., 1984, Host genetic control of mouse hepatitis virus type 4 (JHM strain) replication. I. Restriction of virus amplification and spread in macrophages from resistant mice, J. Gen. Virol. 65:1543.

Kooi, C., Mizzen, L., Alderson, C., Daya, M., and Anderson, R., 1988, Early events of importance in determining host cell permissiveness to mouse hepatitis virus infection, J. Gen. Virol. 69:1125.

Koolen, M. J. M., Osterhaus, A. D. M. E., Van Steenis, G., Horzinek, M. C., and van der Zeijst, B. A. M., 1983, Temperature-sensitive mutants of mouse hepatitis virus strain A59: Isolation, characterization and neuropathogenic properties, Virology 125:393.

Koper, J. W., Lopes-Cardozo, M., Romijn, H. J., and van Golde, E. M. G., 1984, Culture of rat cerebellar oligodendrocytes in a serum-free, chemically defined medium, J. Neurosci. Meth. 10:157.

Krijnse-Locker, J., Ericsson, M., Rottier, P. J. M., and Griffiths, G., 1994, Characterization of the budding compartment of mouse hepatitis virus: Evidence that transport from the RER to the Golgi complex requires only one vesicular transport step, I. Cell. Biol. 124:55.

Krishna, P., and van de Sande, J. H., 1990, Interaction of RecA protein with acidic phospholipids inhibits DNA-binding activity of RecA, J. Bacteriol. 172:279.

Krzystyniak, K., and Dupuy, J. M., 1984, Entry of mouse hepatitis virus 3 into cells, J. Gen. Virol. 65:227.

La Monica, N., Banner, L. R., Morris, V. L., and Lai, M. M. C., 1991, Localization of extensive deletions in the structural genes of two neurotropic variants of murine coronavirus JHM, Virology 182:883.

Lai, M. M. C., 1986, Coronavirus leader-RNA-primed transcription: An alternative mechanism to RNA splicing, Bioessays 5:257.

Lai, M. M. C., 1990, Coronavirus: Organization, replication and expression of genome, Annu. Rev. Microbiol. 44:303.

Lai, M. M. C., Patton, C. D., and Stohlman, S. A., 1982, Further characterization of mRNAs of mouse hepatitis virus: Presence of common 5' end nucleotides, J. Virol. 41:557.

Lai, M. M. C., Baric, R. S., Makino, S., Keck, J. G., Egbert, J., Leibowitz, J. L., and Stohlman, S. A., 1985, Recombination between nonsegmented RNA genomes of murine coronavirus, $J$. Virol. 56:449.

Lamontagne, L., and Dupuy, J. M., 1984a, Persistent infection with mouse hepatitis virus 3 in mouse lymphoid cell lines, Infect. Immun. 44:716.

Lamontagne, L., and Dupuy, J. M., 1984b, Natural resistance of mice to mouse hepatitis virus type 3 infection is expressed in embryonic cells, J. Gen. Virol. 65:1165.

Lamontagne, L., Descoteux, J. P., and Jolicoeur, P., 1989, Mouse hepatitis virus replication in T and B lymphocytes correlate with viral pathogenicity, $I$. Immunol. 142:4458.

Laude, H., Charley, B., and Gelfi, J., 1984, Replication of transmissible gastroenteritis coronavirus (TGEV) in swine alveolar macrophages, J. Gen. Virol. 65:327. 
Lavi, E., Gilden, D. H., Highkin, M. K., and Weiss, S. R., 1984a, Persistence of mouse hepatitis virus A59 RNA in a slow virus demyelinating infection of mice as detected by in situ hybridization, $J$. Virol. 51:563.

Lavi, E., Gilden, D. H., Wroblewska, Z., Rorke, L. B., and Weiss, S. B., 1984b, Experimental demyelination produced by the A59 strain of mouse hepatitis virus, Neurology 34:597.

Lavi, E., Suzumura, A., Hiragama, M., Highkin, M. K., Dambach, D. M., Silberberg, D. H., and Weiss, S. R., 1987, Coronavirus mouse hepatitis virus (MHV)-A59 causes persistent, productive infection in primary glial cell cultures, Microb. Pathol. 3:79.

Lavi, E., Fishman, P. S., Highkin, M. K., and Weiss, S. R., 1988, Limbic encephalitis after inhalation of a murine coronavirus, Lab. Invest. 58:31.

Lavi, E., Suzumura, A., Murray, E. M., Silberberg, B. H., and Weiss, S. R., 1989, Induction of MHC class I antigens on glial cells is dependent on persistent mouse hepatitis virus infection, $J$. Neuroimmunol. 22:107.

Lavi, E., Murray, E. M., Makino, S., Stohlman, S. A., and Lai, M. M. C., 1990, Determinants of coronavirus MHV pathogenesis are localized to $3^{\prime}$ portions of the genome as determined by ribonucleic acid-ribonucleic acid recombination, Lab. Invest. 62:570.

Lazaridis, I., Babich, A., and Nevins, J. R., 1988, Role of adenovirus 72-kDa DNA binding protein in the rapid decay of early viral mRNA, Virology 165:438.

Lee, H.-J., Shieh, C.-K., Gorbalenya, A. E., Koonin, E. V., La Monica, N., Tuler, J., Bagdzhadzhyan, A., and Lai, M. M. C., 1991, The complete sequence (22 kilobases) of murine coronavirus gene 1 encoding the putative protease and RNA polymerase, Virology 180:567.

Leibowitz, J. L., Bond, C. W., Anderson, K., and Goos, S., 1984, Biological and macromolecular properties of murine cells persistently infected with MHV-JHM, Arch. Virol. 80:315.

Le Prévost, C., Verlizier, J. L., and Dupuy, J. M., 1975, Immunpathology of mouse hepatitis virus type 3 infection, $J$. Immunol. 115:640.

Leray, D., Dupuy, C., and Dupuy, J. M., 1982, Immunpathology of mouse hepatitis virus type 3 infection. IV. MHV3-induced immunodepression. Clin. Immun. Immunopathol. 23:539.

Levine, J. M., 1989, Neuronal influences on glial progenitor cell development, Neuron 5:103.

Lillien, L. E., and Raff, M. C., 1990, Differentiation signals in the CNS: Type-2 astrocyte development in vitro as a model system, Neuron 5:111.

Lodish, H. F., and Porter, M., 1981, Vesicular stomatitis virus mRNA and inhibition of translation of cellular mRNA-is there a $\mathrm{P}$ function in vesicular stomatitis virus, $J$. Virol. 38:504.

Loeb, J. E., Cantournet, B., Vartanian, M.-P., Goris, J., and Mervelde, W., 1989, Phosphorylation/ dephosphorylation of $\beta$ light chain of clathrin from rat liver coated vesicles, Eur. J. Biochem. 182:195.

Lucas, A., Flintoff, W., Anderson, R., Percy, D., Coulter, M., and Dales, S., 1977, In vivo and in vitro models of demyelinating diseases: Tropism of JHM strain of murine hepatitis virus for cells of glial origin, Cell 12:553.

Lucas, A., Coulter, M., Anderson, R., Dales, S., and Flintoff, W., 1978, In vivo and in vitro models of demyelinating diseases. II. Persistence and host regulated thermosensitivity in cells of neural derivation infected with mouse hepatitis and measles viruses, Virology 88:325.

Luytjes, W., Sturman, L., Bredenbeek, P. J., Charite, J., van der Zeijst, B. A. M., Horzinek, M. C., and Spaan, W. J. M., 1987, Primary structure of glycoprotein E2 of coronavirus MHV-A59 and identification of the trypsin cleavage site, Virology 161:479.

Luytjes, W., Geerts, D., Posthumus, W., Meleon, R., and Spaan, W., 1989, Amino acid sequence of conserved neutralizing epitope of murine coronaviruses, J. Virol. 63:1408.

MacIntyre, G., Wong, F., and Anderson, R., 1989, A model for persistent murine coronavirus infection involving maintenance via cytopathically infected cell centres, J. Gen. Virol. 70:763.

MacNaughton, M. R., 1982, Occurrence and frequency of coronavirus infections in humans as determined by enzyme-linked immunosorbent assay, Infect. Immun. 38:419.

MacNaughton, M. R., and Patterson, S., 1980, Mouse hepatitis virus strain 3 infection of C57, A/Sn and A/J strain mice and their macrophages, Arch. Virol. 66:71.

Makino, S., and Lai, M. M. C., 1989, Evolution of the $5^{\prime}$-end of genomic RNA of murine coronaviruses during passage in vitro, Virology 169:227.

Makino, S., Taguchi, F., and Fujiwara, L., 1984, Defective interfering particles of mouse hepatitis virus, Virology 133:9. 
Makino, S., Fujioka, N., and Fujiwara, K., 1985, Structure of the intracellular defective viral RNAs of defective interfering particles of mouse hepatitis virus, $J$. Virol. 54:329.

Makino, S., Fleming, J. O., Keck, J. G., Stohlman, S. A., and Lai, M. M. C., 1987, RNA recombination of coronaviruses: Localization of neutralizing epitopes and neuropathogenic determinants on the caroxyl terminus of peplomers, Proc. Natl. Acad. Sci. USA 84:6567.

Mallucci, L., and Edwards, B., 1982, Influence of cytoskeleton on the expression of a mouse hepatitis virus (MHV-3) in peritoneal macrophages: Acute and persistent infection, J. Gen. Virol. 63:217.

Marvaldi, J. L., Lucas-Lenard, J., Sekellick, M. J., and Marcus, P., 1977, Cell killing by viruses. IV. Cell killing and protein synthesis inhibition by vesicular stomatitis virus require the same gene functions, Virology 79:267.

Massa, P. T., and ter Meulen, V., 1987, Analysis of Ia induction on Lewis rat astrocytes in vitro by virus particles and bacterial adjuvants, $J$. Neuroimmun. 13:259.

Massa, P. T., Wege, H., and ter Meulen, V., 1986, Analysis of murine hepatitis virus (JHM strain) tropism towards Lewis rat glial cells in vitro Type I astrocytes and brain macrophages (microglia) as primary glial target cells, Lab. Invest. 55:318.

Massa, P. T., Wege, H., and ter Meulen, V., 1988, Growth pattern of various JHM coronavirus isolates in primary rat glial cell cultures correlates with differing neurotropism in vivo, Virus Res. 9:133.

Massalski, A., Coulter-Mackie, M., Knobler, R. L., Buchmeier, M. J., and Dales, S., 1982, In vivo and in vitro models of demyelinating diseases. V. Comparison of the assembly of mouse hepatitis virus, strain JHM, in two murine cell lines, Intervirology 18:135.

Matsubara, Y., Watanabe, R., and Taguchi, F., 1991, Neurovirulence of six murine coronavirus JHMV variants of rats, Virus Res. 20:45.

McKinnon, R. D., Matsui, T., Dubois-Dalcq, M., and Aaronson, S. A., 1990, FGF modulates the PDGF-driven pathway of oligodendrocyte development, Neuron 5:603.

Mendelman, P. M., Jankovsky, L. D., Murray, R. S., Licari, P., Devald, B., Gerdes, J. C., and Burks, J. S., 1983, Pathogenesis of coronavirus SD in mice. I. Prominent demyelination in the absence of infectious virus production, Arch. Neurol. 40:493.

Miller, C. A., and Carrigan, D. B., 1982, Reversible repression and activation of measles virus infection in neural cells, Proc. Natl. Acad. Sci. USA 79:1629.

Mizzen, L., Cheley, S., Rao, M., Wolf, R., and Anderson, R., 1983, Fusion resistance and decreased infectability as major host cell determinants of coronavirus persistence, Virology 128:407.

Mizzen, L., Hilton, A., Cheley, S., and Anderson, R., 1985, Attenuation of murine coronavirus infection by ammonium chloride, Virology 142:378.

Mizzen, L., MacIntyre, G., Wong, F., and Anderson, R., 1987a, Translational regulation in mouse hepatitis virus infection is not mediated by altered intracellular ion concentrations, J. Gen. Virol. 68:2143.

Mizzen, L., Daya, M., and Anderson, R., 1987b, The role of protease-dependent cell membrane fusion in persistent and lytic infections of murine hepatitis virus, Adv. Exp. Med. Biol. 218:175.

Mobley, J., Evans, G., Dailey, M. O., and Perlman, S., 1992, Immune response to a murine coronavirus: Identification of a homing receptor-negative $\mathrm{CD} 4^{+} \mathrm{T}$ cell subset that responds to viral glycoproteins, Virology 187:443.

Mohandas, D. V., and Dales, S., 1990, In vivo and in vitro models demyelinating disease: A phosphoprotein phosphatase in host cell endosomes dephosphorylating the nucleocapsid protein of coronavirus JHM, in: Coronavirus and Their Diseases (D. Cavanagh and T. D. K. Brown, eds.), pp. 255-260, Plenum Press, New York.

Mohandas, D. V., and Dales, S., 1991, Endosomal association of a protein phosphatase with high dephosphorylating activity against a coronavirus nucleocapsid protein, FEBS Lett. 282:419.

Morris, V. L., Tieszer, C., MacKinnon, J., and Percy, D., 1989, Characterization of coronavirus JHM variants isolated from Wistar Furth rats with a viral-induced demyelinating disease, Virology 169:127.

Muraoka, S., and Takahashi, T., 1989, Primary dissociated cell culture of fetal rat central nervous tissue. II. Immunocytochemical and ultrastructural studies of myelinogenesis, Dev. Brain Res. 49:63.

Murray, R. S., Cai, G.-Y., Hoel, K., Zhang, J.-Y., Soike, K. F., and Cabirac, G. F., 1992a, Coronavirus infects and causes demyelination in primate central nervous system, Virology 188:274. 
Murray, R. S., Brown, B., Brian, D., and Cabirac, G. F., 1992b, Detection of coronavirus RNA and antigen in multiple sclerosis brain, Ann. Neurol. 31:525.

Niemann, H., and Klenk, H.-D., 1981, Coronavirus glycoprotein El, a new type of viral glycoprotein, J. Mol. Biol. 153:993.

Niemann, H., Geyer, R., Klenk, H.-D., Lindner, D., Strim, S., and Wirth, M., 1984, The carbohydrates of mouse hepatitis virus (MHV) A59: Structures of the O-glycosidically linked oligosaccharides of glycoprotein E1, EMBO T. 3:665.

Nishioka, Y., and Silverstein, S., 1978, Requirement of protein synthesis for the degrading of host mRNA in Friend erytholeukemia cells infected with herpes simplex virus, $J$. Virol. 27:619.

Parham, D., Tereba, A., Talbot, P. J., Jackson, D. P., and Morris, V. L., 1986, Analysis of JHM central nervous system infections in rats, Arch. Neurol. 43:702.

Parker, M. D., Yoo, D., and Babiuk, L. A., 1990, Expression and secretion of the bovine coronavirus hemagglutinin-esterase glycoprotein by insect cells infected with recombinant baculoviruses, J. Virol. 64:1625.

Parker, S. E., Gallagher, T. M., and Buchmeier, M. J., 1989, Sequence analysis reveals extensive polymorphism and evidence of deletions within the E2 glycoprotein gene of several strains of murine hepatitis virus, Virology 173:664.

Pasick, J. M. M., and Dales, S., 1991, Infection by coronavirus JHM of rat neurons and oligodendrocyte-type-2 astrocyte lineage cells during distinct development stages, J. Virol. 65:5013.

Pasick, J. M. M., Wilson, G. A. R., Morris, V. L., and Dales, S., 1992, SJL/J resistance to mouse hepatitis virus JHM-induced neurologic disease immunosuppression, Microbiol. Pathol. 13:1.

Pasick, J. M. M., Kalicharran, K., and Dales, S., 1994, Distribution and traffiking of JHM coronavirus structural proteins and virions in primary the OBL-21 neuronal cell line, $J$. Virol. 68:2915.

Pauloin, A., Thurieau, C., and Jolles, P., 1988, Cyclic phosphorylation/dephosphorylation cascade in bovine brain coated vesicles, Biochem. Biophys. Acta 968:91.

Pearce-Kelling, S., Mitchell, W. J., Summers, B. A., and Appal, M. J. G., 1990, Growth of canine distemper virus in cultured astrocytes: Relationship to in vivo persistence and disease, Microb. Pathol. 8:71.

Pearson, J., and Mims, C. A., 1985, Differential susceptibility of cultured neural cells to the human coronavirus OC43, $J$. Virol. 53:1016.

Penman, S., 1965, Stimulation of the incorporation of choline in poliovirus-infected cells, Virology 25:148.

Pereira, C. A., Steffan, A. M., Koehren, F., Douglas, C. R., and Kirn, A., 1987, Increased susceptibility of mice to MHV 3 infection induced by hypercholesterolemic diet: Impairment of Kupffer cell function, Immunobiology 174:253.

Perlman, S., Jacobsen, G., and Moore, S., 1988, Regional localization of virus in the central nervous system of mice persistently infected with murine coronavirus JHM, Virology 166:328.

Perlman, S., Jacobsen, G., and Afifi, A., 1989, Spread of a neurotropic coronavirus into the CNS via the trigeminal and olfactory nerves, Virology 170:556.

Perlman, S., Jacobsen, G., Olson, A. L., and Afifi, A., 1990, Identification of the spinal cord as a major site of persistence during chronic infection with a murine coronavirus, Virology 175:418.

Pickel, K., Muller, M. A., and ter Meulen, V., 1981, Analysis of age-dependent resistance to murine coronavirus JHM infection in mice, Infect. Immun. 34:648.

Plotch, S. J., Bouloy, M., Ulmanen, I., and Krug, R. M., 1981, A unique cap (m7Gpppm)-dependent influenza virion endonuclease cleaves capped RNAs to generate the primers that initiate viral RNA transcription, Cell 23:847.

Raff, M. C., 1989, Glial cell diversification in the rat optic nerve, Science 243:1450.

Raju, R., and Kolakofsky, D., 1988, La Crosse virus infection of mammalian cells induces mRNA instability, $J$. Virol. 62:27.

Reed, S., 1984, The behaviour of recent isolates of human respiratory coronavirus in vitro and in volunteers: Evidence of heterogeneity among 229E-related strains, J. Med. Virol. 13:179.

Rice, A. P., and Roberts, B. E., 1983, Vaccinia virus induces cellular mRNA degradation, J. Virol. 47:529.

Robb, J. A., Bond, C. W., and Leibowitz, J. L., 1979, Pathogenic murine coronaviruses. III. Biological and biochemical characterization of temperature-sensitive mutants of JHMV, Virology 94:385. 
Rodriguez, M., Kenny, J. J., Thiemann, R. L., and Woloschak, G. E., 1990, Theiler's virus-induced demyelination in mice immunosuppressed with anti-IgM and in mice expressing the xid gene, Microb. Pathol. 8:23.

Rottier, P. J. M., and Rose, J. K., 1987, Coronavirus E1 glycoprotein expressed from cloned cDNA localizes in the Golgi region, I. Virol. 61:2042.

Rottier, P. J. M., Brandenburg, D., Armstrong, J., van der Zeijst, B., and Warren, G., 1984, Assembly in vitro of a spinning membrane protein of the endoplasmic reticulum: The E1 glycoprotein of coronavirus mouse hepatitis virus A59, Proc. Acad. Natl. Sci. USA 81:1421.

Sawicki, S. G., and Sawicki, D. L., 1990, Coronavirus transcription: Subgenomic mouse hepatitis virus replicative intermediates function in mRNA synthesis, $J$. Virol. 64:1050.

Schmid, S., Fuchs, R., Kielian, M., Helenius, A., and Mellman, I., 1989, Acidification of endosome subpopulations in wild-type Chinese hamster ovary cells and temperature-sensitive acidificationdefective mutants, J. Cell. Biol. 108:1291.

Schmidt, I., Skinner, M., and Siddell, S., 1987, Nucleotide sequence of the gene encoding the surface projection glycoprotein of coronavirus MHV-JHM, J. Gen. Virol. 68:47.

Schultze, B., Wahn, K., Klenk, H.-D., and Herrler, G., 1991, Isolated HE protein from hemagglutinating encephalomyelitis virus and bovine coronavirus has receptor-destroying and receptorbinding activity, Virology 180:221.

Sekimizu, K., and Kornberg, A., 1988, Cardiolipin activation of dnaA protein, the initiation protein of replication in Escherichia coli, J. Biol. Chem. 263:7131.

Sethna, P. B., Hung, S.-L., and Brian, D. A., 1989, Coronavirus subgenomic minus-strand RNAs and the potential for mRNA replicons, Proc. Natl. Acad. Sci. USA 86:5626.

Siddell, S. G., Barthel, A., and ter Meulen, V., 1981, Coronavirus JHM: A virion associated protein kinase, J. Gen. Virol. 52:235.

Siddell, S. G., Wege, H., and ter Meulen, V., 1982, The structure and replication of coronaviruses, in: Current Topics in Microbiology and Immunology, Vol. 99 (M. Cooper et al., eds.), pp. 131-163, Springer, New York.

Skinner, M. A., and Siddell, S. G., 1983, Coronavirus JHM: Nucleotide sequence of the mRNA that encodes nucleocapsid protein, Nucleic Acid Res. 11:5045.

Sorensen, O., and Dales, S., 1985, In vivo and in vitro models of demyelinating disease: JHM virus in the rat central nervous system localized by in situ cDNA hybridization and immunofluorescent microscopy, I. Virol. 56:434.

Sorensen, O., Percy, D., and Dales, S., 1980, In vivo and in vitro models of demyelinating diseases. III. JHM virus infection of rats, Arch. Neurol. 37:478.

Sorensen, O., Dugre, R., Percy, D., and Dales, S., 1982, In vivo and in vitro models of demyelinating disease: Endogenous factors influencing demyelinating disease caused by mouse hepatitis virus in rats and mice, Infect. Immun. 37:1248.

Sorensen, O., Beushausen, S., Puchalski, S., Cheley, S., Anderson, R., Coulter-Mackie, M., and Dales, S., 1984a, In vivo and in vitro models of demyelinating diseases. VIII. Genetic, immunologic and cellular influences on JHM virus infection on rats, in: Molecular Biology and Pathogenesis of Coronaviruses (P. J. M. Rottier et al., eds.), pp. 279-297, Plenum Press, New York.

Sorensen, O., Coulter-Mackie, M. B., Puchalski, S., and Dales, S., 1984b, In vivo and in vitro models of demyelinating disease. IX. Progression of JHM virus infection in the central nervous system of the rat during overt and asymptomatic phases, Virology 137:347.

Sorensen, O., Beushausen, S., Coulter-Mackie, M., Adler, R., and Dales, S., 1987a, In vivo and in vitro models of demyelinating disease, in: Viruses, immunity and mental disorders ( $\mathrm{K}$. Kurstak, Z. J. Lipowski, and P. V. Morozow, eds.), pp. 199-210, Plenum Press, New York.

Sorensen, O., Saravani, A., and Dales, S., 1987b, In vivo and in vitro models of demyelinating disease. XVII. The infectious process in athymic rats inoculated with JHM virus, Microb. Pathol. 2:79.

Spaan, W., Cavanagh, D., and Horzinek, M. C., 1988, Coronaviruses: Structure and genome expression, J. Gen. Virol. 69:2939.

Stauber, R., Pleiderera, M., and Siddell, S., 1993, Proteolytic cleavage of murine coronavirus surface glycoprotein is not required for fusion activity, J. Gen. Virol. 74:183.

Stewart, J. N., Mounir, S., and Talbot, P. J., 1992, Human coronavirus gene expression in brains of multiple sclerosis patients, Virology 191:502. 
Stohlman, S. A., and Frelinger, J. A., 1978, Resistance to fatal central nervous system disease by mouse hepatitis virus, strain JHM. I. Genetic analysis, Immunogenetics 6:271.

Stohlman, S. A., and Weiner, L. P., 1978, Stability of neurotropic mouse hepatitis virus (JHM strain) during chronic infection of neuroblastoma cells, Arch. Virol. 57:53.

Stohlman, S. A., Baric, R. S., Nelson, G. N., Soe, L. H., Welter, L. M., and Deans, R. J., 1983, Synthesis and subcellular localization of the murine coronavirus nucleocapsid protein, Virology 130:527.

Stohlman, S. A., Matsushima, G. K., Casteel, N., and Weiner, L. P., 1986, In vivo effects of coronavirus-specific $\mathrm{T}$ cell clones: DTH inducer cells prevent a lethal infection but do not inhibit virus replication, J. Immunol. 136:3052.

Stohlman, S. A., Sussman, M. A., Matsushima, G. K., Shubin, R. A., and Erlich, S. S., 1988, Delayedtype hypersensitivity response in the central nervous system during JHM virus infection requires viral specificity for protection, $J$. Neuroimmunol. 19:255.

Stohlman, S. A., Kyuwa, S., Cohen, M., Bergmann, C., Polo, J. M., Yeh, J., Anthony, R., and Keck, J. G., 1992, Mouse hepatitis virus nucleocapsid protein-specific cytotoxic T lymphocytes are Ld restricted and specific for the carboxy terminus, Virology 189:217.

Sturman, L. S., Holmes, K. V., and Behnke, J., 1980, Isolation of coronavirus envelope glycoproteins and interaction with the viral nucleocapsid, J. Virol. 33:449.

Sturman, L. S., Ricard, C. S., and Holmes, K. V., 1985, Proteolytic cleavage of the EL glycoprotein of murine coronavirus: Activation of cell-fusing activity of virion by trypsin and separation of two different $90 \mathrm{~K}$ cleavage fragments, $J$. Virol. 56:904.

Sussman, M. A., Shubin, R. A., Kyuwa, S., and Stohlman, S. A., 1989, T-cell-mediated clearance of mouse hepatitis virus strain JHM from the central nervous system, $J$. Virol. 63:3051.

Suzumura, A., Lavi, E., Weiss, S. B., and Silberberg, D. H., 1986, Coronavirus infection induces H-2 antigen expression on oligodendrocytes and astrocytes, Science 232:991.

Suzumura, A., Lavi, E., Bhat, S., Murasko, D., and Weiss, S. A., 1988, Induction of the glial cell MHC antigen expression in neurotropic coronavirus infections. Characterization of the $\mathrm{H}-2$ inducing soluble factor elaborated by infected brain cells, I. Immun. 140:2068.

Swift, A. M., and Machamer, C. E., 1991, A Golgi retention signal in a membrane-spanning domain of coronavirus El protein, J. Cell. Biol. 115:19.

Taguchi, F., 1993, Fusion formation by the uncleaved spike protein of murine coronavirus JHMV variant c1-2, J. Virol. 67:1195.

Taguchi, F., and Fleming, J. O., 1989, Comparison of six different murine coronavirus JHM variants by monoclonal antibodies against E2 glycoprotein, Virology 169:233.

Taguchi, F., and Siddell, S. G., 1985, Difference in sensitivity to interferon among mouse hepatitis viruses with high and low virulence for mice, Virology 147:41.

Taguchi, F., Goto, Y., Aiuchi, M., Hayshi, T., and Fujiwara, K., 1979, Pathogenesis of mouse hepatitis virus infection. The role of nasal epithelial cells as a primary target of low-virulence virus, MHV-S, Microb. Immunol. 23:249.

Taguchi, F., Siddell, S., Wege, H., and ter Meulen, V., 1985, Characterization of a variant virus selected in rat brains after infection by coronavirus mouse hepatitis virus JHM, $J$. Virol. 54:429.

Taguchi, F., Massa, P. T., and ter Meulen, V., 1986, Characterization of a variant isolated from neural cell culture after infection of mouse coronavirus JHMV, Virology 155:267.

Talbot, P. J., and Buchmeier, M. J., 1985, Antigenic variation among murine coronaviruses: Evidence for polymorphism on the peplomer glycoprotein E2, Virus Res. 2:317.

Talbot, P. J., Salmi, A. A., Knobler, R. L., and Buchmeier, M. J., 1984, Topographical mapping of epitopes on the glycoproteins of murine hepatitis virus-4 (strain-JHM): Correlation with biological activities, Virology 132:250.

Tanaka, R., Iwasaki, Y., and Koprowski, H., 1976, Ultrastructural studies of perivascular cuffing cells in multiple sclerosis brain, $J$. Neurol. Sci. 28:121.

Tardieu, M., Boespflug, O., and Barbe, T., 1986, Selective tropism of a neurotropic coronavirus for ependymal cells, neurons, and meningeal cells, J. Virol. 60:574.

Taylor, C. E., Weiser, W. Y., and Bang, F. B., 1981, In vitro macrophage manifestation of cortisoneinduced decrease in resistance to mouse hepatitis virus, I. Exp. Med. 153:732. 
Tooze, J., Tooze, S., and Warren, G., 1984, Replication of coronavirus MHV-A59 in sac-cells: Determination of the first site of budding of progeny virions, Eur. J. Cell. Biol. 33:281.

Trachsel, H., Sonnenberg, N., Shatkin, A. J., Rose, J. K., Leong, K., Bergmann, J. E., Gordon, J., and Baltimore, D., 1980, Purification of a factor that restores translation of vesicular stomatitis virus mRNA in extracts from poliovirus-infected HeLa cells, Proc. Natl. Acad. Sci. USA 77:770.

van Alstyne, D., and Paty, D. W., 1983, The effect of dibutyryl cyclic AMP on restricted replication of rubella virus in rat glial cells in culture, Virology 124:173.

van Berlo, M. F., Wolswijk, G., Calafat, J., Koolen, M. J. M., Horzinek, M. C., and van de Zeijst, B. A. M., 1986, Restricted replication of mouse hepatitis virus A59 in primary mouse brain astrocytes correlates with reduced pathogenicity, $J$. Virol. 58:426.

van Berlo, M. F., Warringa, R., Wolswijk, G., and Lopez-Cardoso, M., 1989, Vulnerability of rat and mouse brain cells to murine hepatitis virus (JHM-strain): Studies in vivo and in vitro, Glia 2:85.

van Dinter, S., and Flintoff, W. F., 1987, Rat glial C6 cells are defective in murine coronavirus internalization, J. Gen. Virol. 68:1677.

Virelizier, J. L., and Allison, A. C., 1976, Correlation of persistent mouse hepatitis (MHV-3) infection with its effects on mouse macrophage cultures, Arch. Virol. 50:279.

Vlasak, R., Luytjes, W., Leider, J., Spaan, W., and Palese, P., 1988, The E3 protein of bovine coronavirus is a receptor-destroying enzyme with acetyl esterase activity, J. Virol. 62:4686.

Wang, F.-I., Fleming, J. O., and Lai, M. M. C., 1992, Sequence analysis of the spike protein gene of murine coronavirus variants: Study of genetic sites affecting neuropathogenicity, Virology 186:742.

Watanabe, R., Wege, H., and ter Meulen, V., 1983, Adoptive transfer of EAE-like lesions from rats with coronavirus-induced demyelinating encephalomyelitis, Nature 305:150.

Wege, H., Koga, M., Watanabe, R., Nagashina, K., and ter Meulen, V., 1983, Neurovirulence of murine coronavirus JHM temperature-sensitive mutants in rats, Infect. Immun. 39:1316.

Wege, H., Watanabe, H., and ter Meulen, V., 1984, Relapsing subacute demyelinating encephalomyelitis in rats during the course of coronavirus JHM infection, J. Neuroimmun. 6:325.

Weiss, S. B., 1983, Coronaviruses SD and SK share extensive nucleotide homology with murine coronavirus MHV-A59, more than that shared between human and murine coronaviruses, Virology 126:669.

Weiss, S. B., and Leibowitz, J. L., 1983, Characterization of murine coronavirus RNA by hybridization with virus-specific cDNA probes, J. Gen. Virol. 64:127.

Wilbur, S. M., Nelson, G. W., Lai, M. C., McMillan, M., and Stohlman, S. A., 1986, Phosphorylation of the mouse hepatitis virus nucleocapsid protein, Biochem. Biophys. Res. Commun. 141:7.

Williams, R. K., Gui-Sen, J., and Holmes, K. V., 1991, Receptor for mouse hepatitis virus is a member of the carcinoembryonic antigen family of glycoproteins, Proc. Natl. Acad. Sci. USA 88:5533.

Williamson, J. S. P., and Stohlman, S. A., 1990, Effective clearance of mouse hepatitis virus from the central nervous system requires both $\mathrm{CD}^{+}$and $\mathrm{CD} 8^{+} \mathrm{T}$ cells, $J$. Virol. 64:4589.

Wilson, G. A. R., and Dales, S., 1988, In vivo and in vitro models of demyelinating disease: Efficiency of virus spread and formation of infectious centers among glial cells is genetically determined by the murine host, J. Virol. 62:3371.

Wilson, G. A. R., Mohandas, D. V., and Dales, S., 1990, In vivo and in vitro models of demyelinating disease. Possible relationship between induction of regulatory subunit form cAMP dependent protein kinases and inhibition of JHMV replication in cultured oligodendrocytes, in: Coronaviruses and Their Diseases (D. Cavanagh and T. D. K. Brown, eds.), pp. 261-266, Plenum Press, New York.

Yamaguchi, K., Goto, N., Kyuwa, S., Hayami, M., and Toyoda, Y., 1991, Protection of mice from a lethal coronavirus infection in the central nervous system by adoptive transfer of virus-specific T cell clones, I. Neuroimmunol. 32:1.

Yokomori, K., and Lai, M. M. C., 1992, Mouse hepatitis virus utilizes two antigens as alternative receptors, J. Virol. 66:6194.

Yokomori, K., Bakers, S. C., Stohlman, S. A., and Lai, M. M. C., 1992, Hemagglutinin-esterasespecific monoclonal antibodies alter the neuropathogenicity of mouse hepatitis virus, $J$. Virol. 66:2865. 
Yoshikawa, Y., and Yamanouchi, K., 1984, Effect of papaverine treatment on replication of measles virus in human neural and nonneural cells, J. Virol. 50:489.

Zimmer, M. J., and Dales, S., 1989, In vivo and in vitro models of demyelinating diseases. XXIV. The infectious process in cyclosporin A treated Wistar Lewis rats inoculated with JHM virus, Microb. Pathol. 6:7.

Zimprich, F., Winter, J., Wege, H., and Lassmann, H., 1991, Coronavirus induced primary demyelination: Indications for the involvement of a humoral immune response, Neuropathol. Appl. Neurobiol. 17:469.

Zurbriggen, A., Vandevelde, M., and Vollo, E., 1987, Demyelinating, non-demyelinating and attenuated canine distemper virus strains induce oliogodendroglial cytolysis in vitro, J. Neuro. Sci. 79:33. 